Zabytkoznawstwo i Konserwatorstwo XLIV, Toruń 2013

Alicja Saar-Kozłowska

Zakład Muzealnictwa WSP UMK

\title{
Szczęśliwość wieczna królewny Anny Wazówny. W niebie pod kopułą pomnika grobowego*
}

Sczęśliwość wieczna, niebiańska, wolna od niedoskonałości doczesności, trwała i niezmienna jest wprawdzie celem każdego chrześcijanina w życiu rozumianym jako wędrówka przez morze niebezpieczeństw, wiodącym człowieka sprawiedliwego do nieba, jednakże w czasach królewny Anny ustaliły się już odmienne poglądy na wizję zaświatów, warunki uczestnictwa w chwale niebian, drogi osiagnięcia celu w wierności odmiennym wyznaniom, oraz czas dopuszczenia do uczestnictwa w tej chwale po śmierci. Od wieków znano przypadki przeczuć i wizje kształtujące wyobrażenia zaświatów. Podstawę stanowiło Pismo Święte, spuścizna antyczna oraz doświadczenia mistyczne. Tradycja judeochrześcijańska odnotowała przypadki bytności bohaterów biblijnych w niebie, swoistych uprowadzeń za życia, oraz „bytności wizyjne”. Te zaświatowe kontakty, znane z tekstów, kształ-

* Artykuł stanowi pierwszą część tekstu zatytułowanego Szcześliwość wieczna królewny Anny: $w$ niebie pod koputa pomnika grobowego, $w$ orszaku zbawionych $w$ panegiryku żałobnym oraz $w$ trzecim niebie, o którym pisala do pastora Herbergera, który został w skróconej formie wygłoszony na konferencji zatytułowanej: Kultura radości na ziemi wschowskiej (12-13 X 2012). Druga część pracy zatytułowana Szcześliwość wieczna królewny Anny Wazówny: w orszaku z̧bawionych w panegiryku żałobnym Marcina Opitza oraz, $w$ tręecim niebie, o którym pisala do pastora Herbergera została wydrukowana w tomie zawierającym materiały z wymienionej konferencji pt. Kultura radości na ziemi wschowskiej. Obraz uroczystości, jubileuszy, wizyt gości, swiat, red. P. Klint, M. Małkus, K. Szczepańska, Wschowa 2013, s. 221-245. 
tujące powszechne przekonania i wyobrażenia o miejscu nagrody wpływały także na osobiste „doświadczenia” wiernych.

Już sam wybór i wytrwanie w wierze luterańskiej w przypadku Anny Wazówny kształtował dwukierunkową wizję zaświatów, gdzie możliwa była jedynie kara w piekle i nagroda w niebie, z pominięciem stanu pośredniego, jakim dla katolików był czyściec, którego istnienie zostało potwierdzone dekretem na Soborze Trydenckim ${ }^{1}$. Otaczany głębokim szacunkiem przez innowierców święty Paweł w swych Listach odkrywał naturę nieba oraz przekonywał, że chrześcijanie już w czasie swego ziemskiego życia uczestniczą w chwale niebiańskiej², co głosił też w odniesieniu do losów Wazówny autor poświęconego królewnie w 1636 roku panegiryku, niemiecki poeta Marcin Opitz. Według św. Pawła ziemia stała się dla wierzących przedsionkiem nieba, a związek z Bogiem nierozerwalny, dlatego też wydarzenia przyszłe są tak pewne, że mówił o nich już jako o rzeczach dokonanych, a pewność zbawienia stała się podstawowym aspektem eschatologii protestanckiej, którą były też nasycone dzieła sztuki. Chrystocentryczna wizja zmartwychwstania i spraw ostatecznych wyrażała przekonanie, że powstanie Chrystusa z martwych do życia jest wzorem przyszłego losu wiernych - zmartwychwstania ${ }^{3}$. Święty Paweł należał też do tych bohaterów Biblii, którzy zostali porwani do nieba, a świadectwem tego są w kanonicznym zestawie tekstów Pisma Świetego wersety dwunastego rozdziału Drugiego Listu do Koryntian (Kor 12, 2-4), a wśród pism apokryficznych Apokalipsa Pawła. Obrazy nieba przekazywały różnorodne teksty Pisma Świetego, z któ-

1 K. Strzelecka, Cayśsiec, [w:] Encyklopedia katolicka, t. 3, Lublin 1995, szp. 939-942. Kościół katolicki formułował swoją oficjalną doktrynę o czyśćcu w relacji do odmiennych poglądów Kościoła prawosławnego i protestanckiego. Sobór Trydencki (1545-1563) w dekrecie o czyśćcu powtórzył naukę Soboru Florenckiego (1439) o tym, że karze podlegają w nim ci, którzy zakończyli swe życie wprawdzie w miłości Boga, ale jeszcze przed godnym zadośćuczynieniem za popełnione w nim grzechy. Uznano tė̇, że dusze czyśćcowe doznaja pomocy od żyjących wiernych, którzy wstawiaja się za nimi dzięki ofierze mszy, modlitwom oraz jałmużnom, co może wpłynąć na skrócenie pobytu w czyśćcu. Dobro spełniane na ziemi może być skuteczne dla dusz przebywających w nim. Przywódcy reformacji Marcin Luter, Jan Kalwin oraz Ulrich Zwingli całkowicie odrzucili istnienie czyśćca jako sprzeczne z ich wiara w usprawiedliwienie przez łaskę.

2 W. Rakocy, [Niebo] W Biblii, [w:] Encyklopedia katolicka, t. 13, Lublin 2009, szp. 1030.

3 Z. Danielewicz, Niebo. Historia prayszłości, Warszawa 2005, s. 58. 
rych w kontekście tematu przypomnieć należy: List do Hebrajczyleón - zacytowany na pomniku Wazówny, oraz Apokalipse św. Jana - będąca inspiracją autora panegiryku.

W kwestii uczestnictwa zbawionych w niebiańskiej chwale cechą wyróżniająca poglądy reformatorów było przekonanie, że wszyscy oni będą się cieszyć równym szczęściem, w przeciwieństwie do nauczania scholastyków, soborów średniowiecznych oraz późniejszej tradycji katolickiej, ponieważ indywidualna zasługa wiernego nie była zbyt istotna wobec zbawienia, które jest niezasłużonym darem łaski.

Wyrażona w uroczystościach upamiętniających Annę Wazównę szczęśliwość wieczna, jako stan, w którym egzystuje ich zmarła bohaterka, to spełnione marzenie królewny, doświadczone przez nią za życia wizyjnie, w programie uroczystości żałobnych zaś kształtowane przez tradycję i aktualne kody obrazowania oraz tekst Pisma Świetego, a także literaturę apokryficzna. Szczęśliwość wieczna to marzenie każdego wiernego o kresie ziemskiej wędrówki oparte na autorytecie, podziwie i szacunku dla tych, którzy zostali wyróżnieni wzięciem do nieba. Marzenie o nagrodzie dla sprawiedliwego za droge życia w wierze i prawości. Spełnienie oczekiwanej radości - oczekiwanej w wymiarze ogólnym oraz indywidualnym.

W przypadku życia i wydarzeń upamiętniających królewnę Annę Wazównę w roku 1636 mamy do czynienia trzykrotnie z zaświatowymi wizjami. Sa to:

1. Doświadczone przez królewnę odczucie wizji - rodzaju porwania do nieba? Raju? Trzeciego nieba? Tak jak było to udziałem św. Pawła, o czym za jej życia zapewne wiedzieli tylko nieliczni, między innymi słynny wschowski kaznodzieja Waleriusz Herberger.

2. Wizja jej przebywania po śmierci w niebie wykreowana w pomniku grobowym środkami sztuki i niesionymi przez nie treściami, gdzie zasadniczą rolę odgrywaja: koncepcja przestrzenna (portal jako brama-

4 Ibidem, s. 158-159. Doskonałość widzenia Boga w niebie w zależności od wielkości zasług ogłosił w roku 1439 Sobór Florencki. W późniejszym czasie w Pieśni Duchowej świętego Jana od Krzyża (1542-1591), mistyka i ważnej postaci kontrreformacji, czytamy, że w niebie „ci którzy Go lepiej poznaja, tym jaśniej widza Jego nieskończoność, jaka im do zrozumienia zostaje. Tym zaś, którzy mniej Go widza, nie ukazuje się z taką wyrazistością to, co zostało do zobaczenia”. Cyt. za: ibidem, s. 159. 
przejście, umieszczenie figury zmarłej pod łukiem sugerowanego koła-nieba, płytka nisza przeznaczona jedynie dla figury zmarłej, kopuła) oraz wyrażany przekaz o charakterze aksjologicznym dotyczący ziemskich zasług i niebiańskiej nagrody zmarłej (portalowe personifikacje ikonologiczne).

3. Paralelna wizja ugruntowująca przekaz obrazowy, konstruowana słowem oraz realnym (żywym), ruchomym obrazem (orszak odzianych w biel żałobników) w parateatralnych w swym charakterze uroczystościach pogrzebowych, komentowanych publikowanym (i najprawdopodobniej wygłaszanym) tekstem panegiryku ${ }^{5}$, w którym zmarła była sytuowana w Niebieskim Jeruzalem, gdzie została wpisana do księgi żywota, rozkrzewiona przy zdrojach żywych wód, włączona w drzewo zbawienia, a za towarzystwo miała orszak zbawionych odzianych na biało ${ }^{6}$. Wszystkie działania zmierzające do upamiętnienia królewny Anny Wazówny, jak pomnik grobowy, ceremonia pogrzebowa oraz druki okolicznościowe, mają podwójny charakter: zarazem żałobny oraz zdecydowanie triumfujący. W usytuowanym w kościele Wniebowzięcia Najświętszej Panny Marii dziele sztuki, mimo jego sepulkralnego charakteru, są ewidentnie obecne elementy świadczace o stanie niebiańskiej szczęśliwości, w którym znajduje się zmarła bohaterka. Należą do nich:

- lokalizacja w prezbiterium jako w miejscu wyróżnionym w całej świątyni, usytuowanym w pobliżu ołtarza, w nawiązaniu do myśli Marcina Lutra o chórze kościelnym przeznaczonym dla idealnych chrześcijan ${ }^{7}$,

- elementy architektury: portal w formie luku triumfalnego jako brama oddzielająca świat doczesny od sfery pozaziemskiej, kopuła jako symbol nieba,

5 M. Opitz, Panegyricus Serenissimae Suecorum Gothorum ac Vandalorum Principis Annae Heroinae Praestantissimae Honori Piaeque Memoriae Consecratus a Martino Opitio, Thoruni, Ex Officina Schnellboltziana, Iterum editus, Ann MDC XXXVI.

${ }^{6}$ Wprowadzone w Panegiryku Marcina Opitza apokaliptyczne motywy rzeki wody żywej i drzewa życia stanowią obrazy pełni oraz szczęścia życia wiecznego.

7 Por. K. Cieślak, Kościót cmentarzem. Sztuka nagrobna w Gdańsku (XV-XVIII w.). „Dlugie trwanie” epitafium, Gdańsk 1992, s. 20 . Autorka zauważyła, że predellach epitafiów w Gdańsku zmarli w pozie adoranta byli niekiedy lokowani w prezbiterium fantastycznego kościoła, co stanowiło ilustrację wspomnianej powyżej myśli Lutra. 
— program rzeźbiarski: leżąca figura zmarłej usytuowana poza portalembrama, wpisana w łuk arkady portalu, o otwartych oczach kontemplujących zaświaty i rękach złożonych do modlitwy gestem poddania się woli Bożej,

— zestaw trzech figur portalowych jako poświadczenie ziemskich dokonań królewny, otwierających jej bramę nieba wskutek wierności wyznawanej wierze i jej zasadom - co wyraża figura Fides - Wiary, opieki nad bliźnimi personifikowanej przez figurę Gratitudo - Wdzięczności, oraz świadcząca o zwycięstwie w wymiarze ziemskim i niebiańskim Victoria - Zuyciestwo.

Program triumfu, zwycięstwa nad śmiercią oraz wizji nieba kreowany jest w pomniku wieloaspektowo. Poza warstwa personifikacji w jego tworzeniu biorą udział także symbole włączone w program treściowy zabytku w postaci atrybutów figur portalowych ${ }^{8}$. W przypadku figury Zwycięstwa jest to wieniec-korona, który w ,warstwie symboli”, w oderwaniu od personifikacji unaocznia widzowi niebo będące udziałem zmarłej, gdyż korona była jego symboliczną ilustracja jako nagrody dla sprawiedliwych", a ten środek wyrażania treści, podwojony w pomniku przez wieniec-diadem na głowie zmarłej, zostanie potrojony w trakcie ceremonii pogrzebowej poprzez zawieszenie nad leżąca figura pod kopułą kolejnego wieńca ${ }^{10}$. Mamy zatem do czynienia z wieńcem-koroną zwielokrotnionym, oznaczającym szczególne wyróżnienie. Drugi atrybut tej figury, dziś po XIX-wiecznej rekonstrukcji gałązka oliwna, ale pierwotnie palma, jest pradawnym symbolem triumfu.

W przypadku figury Wiary umieszczonej po prawej stronie występuje księga jako przekaz zasad wiary oraz jako księga Pisma Świetego z cyta-

8 Poniższe rozważania oparte zostały na wynikach badań autorki dotyczących próby rekonstrukcji pierwotnej formy pomnika grobowego królewny Anny Wazówny w Toruniu.

9 Zob. S Kobielus SAC, Niebiańska Jerozolima. Od sacrum miejsca do sacrum modelu, Ząbki 2004, s. 191. Autor pisze, że ,jeśli niebo miało być nagrodą dla sprawiedliwych, to najlepiej do symbolicznej ilustracji tej prawdy nadawała się korona. W niektórych tekstach Ksiag Nowego Testamentu przedstawiana była jako «wieniec życia» lub «wieniec chwały»", wskazując na Jk 1,12; Ap 2,10; 1P 5,4 oraz Ap 40,4-10; $14,14$.

10 Zob. Relatio de Augustiis Exequïs Serenissimae Dominae Annae Principis Sveciae felicis memoriae Thoruni Borussorum a.d. XV mens Julii. Ann. MD. C. XXXVI celebratis, Thorunii, Apud Franciscum Schnellboltz. 
tem z Listu do Hebrajczylkóm, mająca także odniesienie do apokaliptycznej księgi żywota akcentowanej w panegiryku Opitza; po lewej stronie znajduje się krzyż jako symbol wiary oraz pokonanej śmierci. Na głowie Wiara ma niewielką czapeczkę, być może jako odniesienie do personifikacji Religii, która w Iconologii Cezarego Ripy na głowie ma welon oznaczający tajemnice wiary.

Figura po lewej stronie portalu, interpretowana jako Wdzięczność, została zaopatrzona w bociana - symbol m.in. miłości do Boga oraz bliźniego, przeciwnika węża - symbolu grzechu, a także kwitnąca gałą́, która w tej warstwie treściowej może - podobnie jaki i bocian - odsyłać do medycznej działalności Anny Wazówny jako jednego ze sposobów spełniania nakazów wiary ${ }^{11}$, a tym samym - oznaczać uzyskanie „przepustki do wieczności”. Jej głowę zdobi diadem zredukowany do formy oprawionego kamienia szlachetnego umieszczonego nad czołem na tle włosów i umocowanego taśmą zawiązaną z tyłu głowy.

W określeniu wymowy treściowej pomnika grobowego istotną rolę odgrywa też wyznaczona przez elementy nośne symbolicznie pionowa oś, która wytyczaja: figura zmarłej, korona zawieszona w czasie uroczystości pogrzebowych, ulokowanie trzech figur w układzie trójkąta $z$ wierzchołkiem na szczycie portalu, gdzie została usytuowana personifikacja Zwycięstwa, w sensie kreowania idei oznaczających zdążanie ku górze. Te zauważone w konstruowaniu wypowiedzi treściowej zależności odgrywają istotną rolę, ponieważ - jak pisze Gaston Bachelard - „wyrażając wartości moralne, nie sposób oderwać się od osi pionowej" "I2. Jean Eduard Cirlot twierdzi, że wszystko, co symboliczne, jest ze swej istoty dynamiczne, toteż pionowość jest utożsamiana z pędem i ruchem pionowym [ku górze - uzup. A.S.-K.], odpowiadającymi w kontekście związku analogicznego między przestrzennością a moralnościa - impulsowi do spirytualizacji. Myśl symboliczna tak wielką wagę przywiązuje do szczebla zajmowane-

${ }^{11} \mathrm{Na}$ ten temat zob.: A. Saar-Kozłowska, Anna Wazónna i Walerian Herberger, [w:] Kościót żtóbka Chrystusa (Kripplein Christi) we Wschowie na tle procesu konfesjonalizacji w krajach Europy Środkowej, red. P. Klint, M. Małkus, K. Szymańska, Wschowa 2012, s. 307-343.

12 Cyt. za: J. E. Cirlot, Pionowość, [w:] Stownik symboli, przekł. I. Kania, Kraków 2000, s. 315, według: G. Bachelard, L'Air et les songes, Paryż 1943. 
go przez daną figurę względem poziomu pośredniego, że często sens tych lub innych form czy istot określa się wyłącznie pod kątem ich usytuowania wzdłuż osi pionowej ${ }^{13}$.

W kontekście analizowanego dzieła sztuki ta zauważona pionowość, tożsama z oznaczeniem wznoszenia się ku górze, wyraża dążenie do wartości wyższych, duchowych, powrót do nieba droga dokonań ziemskich i doskonalenia duchowego. Układ zakończony trzymanym przez umieszczoną na szczycie portalu figurę Zwycięstwa wieńcem triumfu nad zmarłą (wyobrażoną w postaci figury) i jednocześnie koroną żywota przygotowana w niebie przez Chrystusa (dla zbawionej duszy, o czym przekonuje panegiryk Marcina Opitza) oznacza dotarcie do celu wędrówki życiowej człowieka - do nieba.

W organizacji elementów nośnych symbolicznie w dziele sztuki sepulkralnej, jakim jest pomnik grobowy Anny Wazówny, istotna rolę odgrywa też symbolika przestrzeni, gdzie jej wyznacznikami są dwie osie - pionowa, wspomniana już, i pozioma. Sens pionowości lub poziomu odnosi się do analogii między górą i dobrem oraz dołem i tym, co gorsze. „Na płaszczyźnie środkowej - pisze Cirlot - sytuuje się krzyż czterech kierunków (punkty kardynalne) tworzacych kwadrat, stąd jest to symboliczna sfera przejawieniowa"14. Można stwierdzić, że kwadrat sfery przejawieniowejziemskiego świata czasowo-przestrzennego - tworzy w pomniku grobowym Wazówny dolna strefa portalu. „Kierunek poziomy ma związek z możliwościami określonego etapu czy momentu egzystencji - kontynuuje wspomniany autor - pionowy - z jej wzniosłością moralną"15. Oś, na której ułożona jest figura zmarłej, jest podporządkowana osi zachód-wschód, gdzie na zachód - utożsamiany z ideą śmierci i ciemności - jest skierowana głowa, natomiast na wschód - utożsamiany z duchową iluminacja - skierowana jest twarz i wzrok postaci. Zachód oznacza więc tu przeszłość ziemską zmarłej, wschód niebiańska przyszłość, a nawet - w kontekście panegiryku napisanego na jej cześć - aktualną teraźniejszość (stan zbawienia). Zgodnie z przekonaniem mistyka i teologa katolickiego, przyjaciela św. Bernar-

13 Ibidem.

14 J. E. Cirlot, Przestrzeń, [w:] Stownik symboli, s. 336.

15 Ibidem. 
da z Clairvaux, rozważającego m.in. naturę ciała i duszy, Wilhelma z Saint Thierry (1075/1080-1148), „dusza dąży w górę, aby osiagnąć życie niebiańskie", co wyraził, opisując jej siedem stopni ${ }^{16}$.

W tworzeniu i wykorzystywaniu dla celów ideowego przekazu przestrzeni w pomniku grobowym Anny Wazówny istotną rolę odgrywa też symbolika strony prawej i lewej. Na portalu lewą stronę naczółka zajęła figura określająca ziemskie dokonania zmarłej w kategoriach życia aktywnego zrealizowane poprzez szeroko rozumianą dobroczynność, prawa zaś, zawsze uprzywilejowana, figura wyrażająca duchowy aspekt życia - życia kontemplacyjnego wyróżnionego zajmowaną pozycja - choć obie personifikacje są usytuowane na ramionach trójkąta równobocznego, obie zatem są równoważne, i obie doprowadziły zmarłą do zwycięstwa w ziemskiej wędrówce rozumianej jako powrót do raju ${ }^{17}$. Triumf nad śmiercią i zwycięstwo akcentowal też charakter ceremonii pogrzebowej oraz treści druków okolicznościowych, które dopełniały wyraz idei zawartych w pomniku nagrobnym oraz komentowały uroczystości upamiętniające królewnę Annę Wazównę.

Określona rolę w przekazywaniu idei w pomniku grobowym królewny Anny odgrywa też detal architektoniczny w postaci chust w przyłuczach arkady portalu, stanowiących zredukowaną formę kotar lub zasłon. Mogły one funkcjonować w dziełach sztuki osobno, niezależnie od programu treściowego zabytku, pełniąc jedynie funkcję ozdobną. Jednakże w tym wypadku wyrzeźbione tkaniny, jakby podciagnięte przy prześwicie arkady, mogą mieć też znaczenie symboliczne i w tej funkcji stanowią granicę świa-

16 Ibidem.

17 Ibidem, s. 337. J. E. Cirlot pisze, że strona prawa uzyskuje określniki witalności, lewa zaś charakter funeralny. „Inną tego konsekwencja, widoczną w alegoriach i emblematach, jest to, że stronie prawej odpowiadaja cnoty - jeśli można tak powiedzieć - wyższe, jak współczucie, lewej zaś - sprawiedliwość", i to sprawdziło się w przypadku pomnika grobowego Anny Wazówny, gdzie po prawej stronie portalu znajduję się personifikacja cnoty teologalnej - Wiary, po lewej zaś - Wdzięczności, w pewnym sensie pokrewna cnocie Sprawiedliwości. Cirlot podkreślił, iż „trzeba pamiętać, że ta symbolika stref przestrzeni nadaje formę wszelkiemu innemu symbolowi materialnemu, czy to naturalnemu, czy też artystycznemu lub graficznemu, jako że każdy znajduje się w przestrzeni bądź go dookreśla" (ibidem, s. 338). 
tów ${ }^{18}$. Biała barwa kamienia, z której wykuto postać zmarłej, poza swoista modą oraz walorami formalnymi, korespondowała z bielą strojów żałobników podczas toruńskiego pochówku w roku 1636 jako oznaka czystości zmarłej, niezamężnej kobiety, symboliczne znaczenie triumfu oraz antycypacja i unaocznienie odzianego w biel orszaku zbawionych w Niebiańskiej Jeruzalem, do której bohaterka już trafiła, o czym przekonywał panegiryk, a wizualizował kondukt żałobników. Myśli o Niebiańskim Jeruzalem ewokował też zacytowany fragment z Listu do Hebrajcaylkón, a oglądanie tego, co dla śmiertelników niewidzialne, czyli nieba - otwarte oczy figury zmarłej.

Symbolicznie lokują też zmarłą królewnę w niebie doskonałe figury geometryczne, których kształt nadano partiom jej pomnika grobowego:

- kwadrat ziemskiej rzeczywistości w kolumnowej partii portalu,

- koło nieba, zarysowane realnie półkolistym łukiem arkady, na średnicy którego leży figura zmarłej wpisana w prześwit portalu, oraz koło jakby zamykające się pod nią, dopełnione w wyobraźni widza, stymulowanej czytelną koncepcją dzieła sztuki,

— trójkąt zwieńczenia, w którym określone zostały ziemskie zasługi zmarłej.

W symbolice wprowadzonej przez funkcjonujące $\mathrm{w}$ formie pomnika grobowego Anny Wazówny figury geometryczne istotne jest też umieszczenie koła (wyprowadzonego z prześwitu arkady) w obrębie kwadratu (kolumnowej partii portalu), co wyraża tu „przejście” od ujętego portalem-bramą-światów kwadratu, oznaczającego ziemską egzystencję, do znajdującego się w jego obrębie koła oznaczającego świat niebiański. „Przejście”, które stało się udziałem zmarłej królewny, na co w ten właśnie sposób wskazuje dzieło sztuki. Usprawiedliwienie pożądanej zmiany stanu znajduje się ponad oznaczeniem tego zasłużonego procesu w górnej, nasadzonej na kwadrat kompozycji architektoniczno-rzeźbiarskiej, określonej przez figurę trójkąta równobocznego, niosącej przekaz biograficzny.

Warto przypomnieć, że filozofowie, teolodzy i mistycy wszystkich czasów w różnorodny sposób próbowali zobrazować głębokie myśli, także religijne, za pomoca geometrii, a figury geometryczne należy traktować jako

18 J. Białostocki, Drani śmierci. Antyczny symbol grobony i jego tradycja, [w:] idem, Symbole i obrazy w śniecie sætuki, Warszawa 1982, s. 158-186, zwłaszcza s. 169. 
narzędzia - jak pisze Dorothea Forstner - „za pomocą których Stwórca ukształtował rzeczy widzialne i wycisnął na nich swa pieczęć, ślady mądrości Bożej, którą «wylał na wszystkie swe dzieła»" (Syr 1,9) 19 .

W rozważaniach należy wziąć też pod uwagę symbolikę numerologiczną, w myśl której kwadrat ziemski odnosi się do liczby 4, trójkąt zaś do liczby 3, oznaczając m.in. impuls ku jedności najwyższej, od tego, co rozciagle, wyobrażone przez podstawę, ku nierozciagłości wyobrażonej przez wierzchołek ${ }^{20}$. Trójkąt jest figurą doskonała. Oznacza także Chrystusa. Wprowadzone w krag rozważań poprzez figury geometryczne wykorzystane w formie pomnika Wazówny liczby dają sumę 7. Siedem punktów określa przestrzeń poprzez 6 punktów sytuacyjnych oraz punkt centrum, a siedem punktów przestrzeni uważano za źródło wszystkich układów siódemkowych. W zakresie symboliki liczb reprezentacyjne symbolicznie sa właśnie: trójnia oznaczająca porządek umysłu bądź ducha, czwórnia wyrażająca porządek ziemski, siódemka oznaczająca porządek planetarny i moralny, dwunastka - porządek kosmiczny. Trójka to m.in. harmoniczny wynik działania jedności na dwa. Wyraża też dostateczność. Także rozwój jedności we własnym wnętrzu. Jest liczbowym upojęciowieniem nieba i Trójcy. Oznacza syntezę duchowa. Cztery to symbol ziemi, ziemskiej przestrzenności, usytuowania, naturalnych granic zewnętrznych, racjonalnego uporządkowania. Siedem to porządek kompletny, okres, cykl, połączenie trójni z czwórnią, dlatego przypisuje się tej liczbie szczególną wartość. Odpowiada, jak zostało wspomniane, siedmiu kierunkom przestrzeni, gwieździe siedmioramiennej, a także - co w toku niniejszych rozważań szczególnie istotne połączeniu kwadratu z trójkątem poprzez nałożenie tego ostatniego (lub wpisanie go w kwadrat), oznaczające jakby nałożenie nieba na ziemię, co ma właśnie miejsce w pomniku grobowym Anny Wazówny. Warto przypomnieć, że siedem to również wymiar podstawowej skali dźwięków, planet, kolorów, liczba cnót teologalnych i kardynalnych, siedmiu darów Ducha Świętego, a utworzenie geometrycznej wizualizacji tych liczbowych zależności w dziele sztuki sepulkralnej nie było przypadkowe, ponieważ licz-

19 D. Forstner OSB, Świat symboliki chrześcijańskiej, przekł. i oprac. W. Zakrzewska, P. Pachciarek, R. Turzyński, wybór ilustracji i komentarz T. Łozińska, Warszawa 1990, s. 55.

20 Ibidem, s. 425. 
ba symboliczna pozostaje w wewnętrznym związku z rzecza, do której się odnosi z racji mistycznej więzi między tym, co liczone, a liczbą ${ }^{21}$.

\section{Koło nieba i brama nieba}

Wyobrażenie w toruńskim pomniku grobowym zmarłej królewny pod łukiem, jakby w zarysie koła, które powstaje po dopełnieniu rzeczywistego łuku arkady, w prześwicie portalu, traktowanego jako brama-przejście, w sposób wyrazisty sytuowało ją w niebie - w miejscu stanowiącym kres jej życiowej wędrówki, pożądanym miejscu szczęśliwości wiecznej, gdzie trafiaja sprawiedliwi. Zostało to wyrażone poprzez proste kształty figur geometrycznych oraz powściagliwe $\mathrm{w}$ formie i precyzyjnie określone w ikonologicznym kodzie personifikacje - świadectwa życia zrealizowane w postaci figur portalowych.

Taki sposób określenia lokalizacji osoby zmarłej w niebie ma, jak wiadomo, długa i bogata tradycję. W różnych epokach stylowych w sposób charakterystyczny wyobrażano wejście w świat pozaziemski poprzez właściwe im formy architektoniczne. W czasach renesansu posługiwano się w tym celu portalem kolumnowym, a kolumnie przywrócono funkcję oznaczania wywyższenia, jaką pełniła w czasach antycznych ${ }^{22}$.

Motyw drzwi w sztuce sepulkralnej znany jest od czasów antyku, a ideę Niebiańskiej Jerozolimy wyrażano już na wczesnochrześcijańskich sarkofagach. Rozbudowana architektonicznie brama ewokowała ideę nieba i stanowiła granicę między dwoma światami ${ }^{23}$. Istotne dla naszych rozważań jest to, że zmarli, ukazani jako stojący w rozbudowanej architekturze bramy o formie baldachimu, mieli oczy otwarte. Wskazywało to - jak pisze Stanisław Kobielus - na ich pełną świadomość rzeczy niewidzialnych.

${ }^{21}$ Ibidem, Liczby, s. 224-229.

${ }^{22}$ K. Cieślak, Kościót - cmentarzem. Sztuka nagrobna w Gdańsku (XV-XVIII w.). „Dlugie trwanie epitafium", Gdańsk 1992, s. 70.

${ }^{23} \mathrm{Na}$ średniowiecznych płytach nagrobnych ustawianych w pozycji leżącej wyobrażane postacie zmarłych przedstawiane były w postawie stojącej, co miało oznaczać trwanie w wierze, pozycja leżąca zaś poddanie się występkom lub pokusom. Zob.: S. Kobielus SAC, op. cit., s. 166. 
Patrzyli jeszcze na opuszczany świat, lecz zdawali się już widzieć inny wymiar, który wkrótce miał się ujawnić. Świadczyło to także o tym, że życie przyszłe nie mogło utożsamiać się tylko ze śmiercią. Komentują to słowa Hildeberta z Tours: „kto stoi w bramie, częściowo jest widziany i częściowo niewidziany". Śmierć była tylko przejściem, bramą. Przestapić przez bramę oznaczało zatem zmienić stan egzystencji, w tym przypadku przejść ze śmierci do życia ${ }^{24}$.

Przypomnijmy, że leżąca na posłaniu figura zmarłej znajduje się pod półkolistym łukiem zarysowanym przez prześwit arkady portalu, jednocześnie jest w obrębie koła, które można by zarysować, dopełniając ten łuk, cała figura mieści się w górnej części tego koła, a na jego średnicy leży jej posłanie. Wszystkie te zabiegi kompozycyjne służą nie tylko kwestiom formalnym, wprowadzając ład i prostotę w harmonijna kompozycje poszczególnych elementów dzieła, ale w sposób jasny wyrażaniu określonych treści. Przedstawianie postaci pod łukami i w niszach, raczej w pozycji stojacej, od czasów starożytnych służyło ich wywyższeniu i gloryfikacji. W tym wypadku figura zmarłej, wyobrażająca bohaterkę w wizji zaświatowej, którą materialnie realizuje dzieło sztuki, znajduje się w sugerowanym poprzez formy architektoniczne kole, które symbolizowało niebo, a tym samym Jerozolimę Niebiańską ${ }^{25}$. Koło jest też jedną z figur idealnych, którą chętnie posługiwano się dla przekazania określonych treści symbolicznych. Podobna zasadę kompozycyjna, polegająca na sytuowaniu figury zmarłego na średnicy sugerowanego w formie pomnika grobowego koła, zastosowano w renesansowych nagrobkach królewskich znajdujących się na Wawelu ${ }^{26}$.

24 Ibidem, s. 166.

25 S. Kobielus, op. cit., s. 126.

26 Zob. W. Krasowski, O kilku kompozycjach opartych na odwzorowaniu podziatón sfery niebieskiej, [w:] Renesans. Sztuka i ideologia, Materiały Sympozjum Naukowego Komitetu Nauk o Sztuce PAN oraz Sesji Naukowej Stowarzyszenia Historyków Sztuki, Kielce, listopad 1973, Warszawa 1976, s. 381-399, a zwłaszcza s. 391. Usytuowania „,asesorów” towarzyszacych Chrystusowi w scenie Sądu Ostatecznego w trzecim niebie poza sferą niebieską dopatrzył się Witold Krasowski w swej analizie gdańskiego ołtarza Sądu Ostatecznego Memlinga w artykule zatytułowanym O kilku kompozycjach opartych na odwzorowaniu podziatów sfery niebieskiej, [w:] Renesans. Sqtuka i ideologia. Autor udowadnia, że „chyba można sądzić, iż sceny na gdańskim tryptyku nie tylko przedstawiono na podstawie naukowych, a do dziś aktualnych metod dwuwymiarowego odwzorowywania zjawisk dziejących się w kosmosie, i nie 
Warto przypomnieć też, że już od czasów antycznych zastosowanie kolumn przy posagach oraz przedstawianie postaci pod łukami i w niszach, raczej w pozycji stojącej, służyło ich wywyższeniu i gloryfikacji, co poświadcza nie tylko praktyka artystyczna, ale i Pliniusz Starszy w swojej Historii naturalnej ${ }^{27}$. Zastosowanie w portalu motywu łuku triumfalnego również oznaczało wywyższenie i triumf zmarłej, co dodatkowo podkreśla program heraldyczny i alegoryczny.

Elementy architektoniczne wyrażały ideę granicy pomiędzy dwoma typami egzystencji. Arkady obramowujące postacie zmarłych w gotyckich płytach grobowcowych wykazuja podobieństwo funkcjonalne do drzwi. Te architektoniczne obramowania oddzielaja nadnaturalna przestrzeń od rzeczywistej" ${ }^{28}$. Znane są też sarkofagi stojące jakby w otwartym wejściu, jak na przykład autorstwa Piero di Nicolo (możliwy udział Donatella) grobowiec Onofrio Strozziego (wykonany 1417), znajdujący się w Santa Trinita we Florencji. Wyrażano też opinię, że „kto zmarłego grzebie pod łukiem [...] przejawia pewien określony pogląd byt zmarłego"29. $\mathrm{Na}$ temat symboliki łuku Hans Gerhard Evers wypowiedział się w następujący sposób: „Wygię-

tylko związano je z położeniem geograficznym, hrabstwa Flandrii. Sceny te przedstawiając Sąd Ostateczny są zarazem ilustracją tekstów liturgicznych przewidzianych na dzień święta zmarłych wiernych” (s. 396-397). Krasowski pragnie zwrócić uwagę na nagrobki Zygmunta Starego i Barbary z Rożnowa, w których figura przedstawiająca zmarłego spoczywa w półkoliście zamkniętej niszy. Jego zdaniem „można dojść do wniosku, że jeśli wewnętrzna strona archiwolty odwzorowuje równik, to postać zmarłego jest usytuowana w strefie wydzielonej przez «linea crepusculina», wykreśloną dla [...] Krakowa”. Według badacza „półkolista archiwolta nagrobka może odwzorowywać tu równik, ponieważ byłoby to zgodne z biblijnymi wyobrażeniami o firmamencie w kształcie półkuli podpartej słupami, wznoszącej się nad ziemią kolistą i płaską. Za obrazowaniem przez archiwoltę firmamentu przemawia zresztą umieszczenie w nagrobku Zygmunta Starego na jej podniebieniu różyc, a nad nią, w „trzecim niebie”, głów aniołów” (s. 398).

${ }_{27}$ Pliniusz Starszy, Historia naturalna, [w:] Myśliciele, kronikarze i artyści o sżtuce od starożytności do 1500, wybrał i opracowal J. Białostocki, wyd. 2 poprawione, Warszawa 1988, s. 137. Białostocki podkreśla (przyp. 6 na s. 158), że symbolika kolumn i łuków oznaczająca wywyższenie osoby, której towarzyszyły, przetrwała w czasach nowożytnych w pomnikach i portretach, w których tle pojawiały się kolumny i arkady aż do XVIII w.

28 J. Białostocki, op. cit., s. 169-170.

29 Ibidem, s. 170, przyp. 41 na tej stronie. Białostocki zacytował: F. Möbius, Über und unter dem Bogen. Zur Ausdrucksbedeutung zpeier Formzonen, [w:] Festschrift J. Jahn, Leipzig 1958, s. 73-82, zwłaszcza s. 80. 
cie łuku ponad postacią lub napisem oznacza umieszczenie tam świętego znaku wywyższenia, godności, władzy; jest to magiczna formuła, udzielająca postaci znaczenia" 30 .

Choć w przypadku niektórych nagrobków nie można mówić o drzwiach w sensie dosłownym, „widz ma jednak wrażenie, że stoi przed portalem zapowiadającym inny świat, w który triumfalnie wkracza zmarly", tak jak w grobowcach papieży z rodu Medyceuszy w Santa Maria Sopra Minerwa w Rzymie (Leona X, 1513-1523 i Klemensa VII, 1523-1534), autorstwa Baccio Bandinellego, gdzie postać została pokazana na ciemnym tle wielkiej niszy „otwierającej się w kompozycji architektonicznej o charakterze łuku triumfalnego" ${ }^{31}$.

Także wtedy, kiedy motyw łuku triumfalnego nie został w grobowcu wprowadzony, jak w monumentum Henryka II i jego żony, wykonanym przez Francesco Primaticcia i Germaina Pilona (około 1563, Opactwo Saint Denis), symboliczne znaczenie portalu jest oczywiste ze względu na umieszczenie monumentalnych, otwartych drzwi w krótszej ścianie dolnej kondygnacji grobowca. „Przez te drzwi - jak pisze Jan Białostocki - możemy zajrzeć w prawdziwy świat śmierci, do którego należą ciała monarchy i monarchini «en transis»" ${ }^{\prime 2}$. Od czasów starożytności drzwi miały bogaty repertuar znaczeń; „w sztuce antyku były «drzwiami śmierci», za którymi zaczynał się posępny świat starożytnej eschatologii, w późnoantycznym okresie wszakże zapowiadały one niekiedy po ich przekroczeniu uzyskanie «korony żywota»" ${ }^{33}$.

W pomniku grobowym królewny Anny Wazówny, w pierwotnej wersji projektu architektoniczno-rzeźbiarskiego nie mamy do czynienia $\mathrm{z}$ rzeczywistymi drzwiami ${ }^{34}$. Istnieje ścisłe zespolenie nagrobka umiesz-

30 H. G. Evers, Tod, Macht und Raum als Bereiche der Architektur, München 1939, s. 105. "Wo ein Bogen über einen Gestalt oder über einer Schriftsatz geschlagen ist, da ist das heilige Zeichen der Erhöhung, des Ranges, der Macht über diese Gestalt gesetzt, ein Zauberspruch, der ihr Bedeutung verleiht”. Cyt. w tłumaczeniu J. Białostockiego, s. 170, przyp. 41.

31 J. Białostocki, op. cit., s. 170-171.

32 Ibidem, s. 173.

33 J. Białostocki, Symbolika drzwi w sepulkralnej sztuce baroku, [w:] Sarmatia artistica. Ksiega pamiatkowa ku czci profesora Wtadystawa Tomkienvicza, Warszawa 1968, s. 114.

34 Wiadomo, że istniały różne wersje zabytku: z zamknięciem wysokimi drzwiami, bez jakiegokolwiek zamknięcia oraz z niskim płotkiem. Naszym zdaniem pierwotny projekt nie 
czonego wewnątrz niszy oraz zewnętrznego portalu, które forma wysokiego zamknięcia by niweczyła. Nagrobek jest wpisany w zarys łuku arkady, przez która jest oglądany, ukazuje się widzowi w nim lub pod nim, widać go jakby w arkadowym przejściu.

Okazały portal w przypadku grobowca Wazówny ni e jest więc rodzajem ozdobnego architektoniczno-rzeźbiarskiego obramienia rzeczywistego wejścia do wnętrza grobowca jako przestrzeni przeznaczonej także dla widza; przestrzeń jest płytka. Znaczna jej część zajmuje przyścienny, plastycznie potraktowany nagrobek, nie ma elementów umożliwiających sprawowanie funkcji liturgicznych, nadających wnętrzu charakter kaplicy. Niestaranny od strony kościoła sposób opracowania partii ścian niszy oraz kształt kopuły spłaszczonej z tej samej strony sugerują brak dopuszczenia do oglądania grobowca z innej pozycji niż z zewnątrz. Portal więc, obok swej rzeczywistej funkcji obramienia prześwitu arkady pozwalającej zajrzeć do środka niszy oraz nośnika informacji o zmarłej o charakterze genealogiczno-alegorycznym, pełni też funkcje czysto symboliczne. Widz ma wrażenie, że stoi przed konstrukcja zapowiadająca inny świat, w którym znajduje się zmarła. Portal i występujący w nim łuk wraz z całym obramowaniem architektoniczno-rzeźbiarskim przejmuje tutaj funkcję drzwi wyrażających ideę przejścia w zaświaty, która jest przez nie symbolizowana w dziełach sztuki nagrobnej. Portal ten jest barierą nie do przebycia dla żywych, granicą dwu światów i bramą prowadzącą w zaświaty, do nieba. W związku z taką koncepcja przestrzenną zrealizowaną w toruńskim pomniku figura zmarłej widziana $z$,zewnątrz” pozostaje wobec widza $w$ innym świecie i ogląając niewidzialnego dla nas Boga, lekko unosi się przed nim ze swego posłania, co zostało wyraźnie określone poprzez formę rzeźby. Ma otwarte oczy, którymi ogląda już świat niebiański, i ręce złożone do modlitwy gestem poddania się woli Bożej. Patrzący na pomnik zagląda doń przez łuk portalu i widzi bohaterkę usytuowaną w niebie, ale do wejścia do wnętrza grobowca nie jest upoważniony. Usprawiedliwiona i upoważniona do przekroczenia tej granicy w sensie duchowym i artystycznej wi-

przewidywał żadnego zamknięcia arkady portalu, tak jak dokumentuje to grafika Henryka Sierakowskiego z roku 1792. 
zualizacji była szwedzka księżniczka dzięki swym zasługom, o których zaświadcza program ideowy portalu.

Widz wzrokowo odbiera formy portalu, nie poznaje ich bliżej od środka niszy, ponieważ jest sugerowane nieprzekraczanie jego granic. Dolna część portalu została zamknięta w formę kwadratu, a jego zwieńczenie w kształt trójkąta równobocznego. Występują więc dwie następne idealne figury geometryczne, które z jednej strony -podobnie jak w przypadku koła wpisanego w kompozycję portalu - porządkują układ elementów, nadając mu spokój i klasyczną harmonię, z drugiej zaś niosą przekaz treściowy. Cała kompozycja w swym układzie graficznym czy też figur geometrycznych stanowi zarys bramy do nieba, w którym już została osadzona zmarła (symbolizowanym przez koło), a dostapiła tej nagrody za dokonania w swym życiu doczesnym (symbolizowanym przez kwadrat oznaczajacy ziemię), spełniając zadania życiowe poprzez dwie równoważne drogi ziemskiej aktywności (personifikacja Gratitudine) i duchowej kontemplacji (personifikacja Fede (hristiana), jak równoważne są ramiona trójkąta równobocznego, osiagając zwycięstwo w sferze ziemskiej i niebiańskiej. Tak jak to sugeruje wpisane w kwadrat koło ${ }^{35}$.

35 Katarzyna Cieślak (op. cit., s. 73-74), badając gdańskie epitafia, odnalazła zależność figur geometrycznych określających formę dzieła sztuki (w odniesieniu do znanego w sztuce i literaturze konfliktu cnoty i Fortuny, gdzie cnota jest lekiem na zmienność losu) w epitafium Bartłomieja Schachmanna (1607, uzupełnianie do r. 1625; zob. w Internecie: http:// commons.wikimedia.org/wiki/File:Epitafium_Schachmanna.jpg) z kościoła Najświętszej Panny Marii w Gdańsku. W zabytku tym portret zmarłego wyobrażonego z czaszką w ręce - atrybutem Quies (bogini spokoju z mitologii rzymskiej) - wpisany został w koło interpretowane przez badaczkę jako koło Fortuny - tożsame dla osoby upamiętnionej z boską Opatrznością, które zostało wpisane w ramę o niemal kwadratowym kształcie. Autorka pisze, że figury geometryczne: koło i kwadrat, tak jak i odpowiadające im bryły: kula i sześcian, łączone są z pojęciami Fortuny i Cnoty. Katarzyna Cieślak (s. 74) przypomniała, że na karcie tytułowej paryskiego wydania De remediis utriusque fortunae Petrarki z roku 1523 (zob. w Internecie: http://luna.folger.edu/luna/servlet/view/all/what/[De\%20remediis\%20 utriusque $\% 20$ fortunae. $\% 20$ French. $\% 20$ Selections. $\% 201523]$ ?os $=0 \& p g s=50$ dostęp marzec 2013 r.) znajdowało się drzeworytnicze przedstawienie siedzącej na kuli Fortuny oraz Cnoty wyobrażonej na sześcianie, opatrzone napisami: Sedes Fortune Rotu[n]da natomiast Sedes Virtutis quadrata. Dzięki cnocie człowiek zyskuje poczucie bezpieczeństwa i dlatego też Schachmann kazał się przedstawić jako Beatuss Submissus, definiując tym samym swoje miejsce po śmierci w świecie całkowicie poddanym woli Boga, co symbolizuje koło (atrybut Fortunae christianae) wpisane w kwadrat. Aby uzasadnić swoją interpretację, autorka dodała 
Warto przypomnieć, że kolistą formę nadawano Niebiańskiej Jerozolimie przedstawianej w sztukach pięknych; czasami stosowano też kształt kwadratu lub wieloboku. W wieku XV realizacje Niebiańskiej Jerozolimy przybierały wygląd światyni lub zbliżonej do niej budowli z jedna brama, przez którą wprowadzani byli lub zapraszani zbawieni ${ }^{36}$. Wspaniałe bramy nieba sa znane $z$ realizacji malarskich najznakomitszych twórców malarstwa, jak Rogier von der Weyden czy też Hans Memling. Przytaczanie licznej i różnorodnej grupy przykładów obrazujących w sztuce ideę Niebiańskiej Jerozolimy przekracza ramy tego tekstu, trzeba jednak podkreślić, że istnienie grupy zabytków dowodzi, że do interpretowania elementów architektury w kategoriach form niebiańskiej symboliki widzowie byli od wieków wprowadzeni. Funkcjonowanie motywu przejścia wyrażanego poprzez rzeczywiste, obecne w sztuce sepulkralnej drzwi, drzwi adaptowane i jedynie wyobrażone też zostało szczegółowo omówione, w literaturze polskiej przede wszystkim przez Jana Białostockiego. Zdaniem badacza taką samą rolę granicy, bramy, przejścia z jednej rzeczywistości w druga odgrywaja łuki, portale oraz ewokują kotary, także te zmniejszone w swej skali do roli chust, traktowanych najczęściej jako element jedynie ozdobny ${ }^{37}$.

też, że w drugim tomie Symbola Varia... Jakuba Typotiusa (Praga 1602) w emblemie „Fata obstant" (zob. np.: Glasgow University Emblem Webside, French Emblems at Glasgow, Claude Paradin, Devices herö̈ques, 1551: http://www.emblems.arts.gla.ac.uk/french/emblem. php?id=FPAa096dna dostęp marzec 2013 r.) znajdujemy koło Fortuny przykute łańcuchem do kwadratowej płyty, a ramę iconu tworzy koło wpisane w kwadrat, komentarz zaś głosi, że przyczyną sprawczą wszelkich kolei losu jest Bóg. Cieślak wskazała też na inne realizacje, gdzie zastosowano połączenie kształtu koła i kwadratu, takie jak: pomnik epitafijny markiza d Ori, 1605-1614, jako efekt wyboru Schachmanna, oraz kształt tablicy inskrypcyjnej pomnika epitafijnego Bartłomnieja Keckermanna, 1623, oba w kościele św. Trójcy w Gdańsku. Powyższe przykłady dokumentują sposób rozumienia zastosowanych w pomnikach nagrobnych form geometrycznych oraz świadomość ówczesnych fundatorów i odbiorców ich symbolicznego przesłania.

36 S. Kobielus, op. cit., s. 142-144, 155, 157, 161.

${ }^{37}$ J. Białostocki, Symbolika drzwi w sepulkralnej sætuce baroku, s. 107-119; idem, Dræwi śmierci, s. 158-186; J. Samek, Porta angusta $i$ nagrobki portalowe w Polsce (rapoznana symbolika wejścia w sz̨tuce), Folia Historiae Artium, t. XVI (1980), s. 141-159; R. Mączeński, Warszawski pomnik Jana Tarly, „Ochrona Zabytków”, XLIX: 1996, nr 2, s. 159-166. 
Wiadomo też, że gdy figury geometryczne kształtują bryły architektoniczne, w przekazie treściowym dochodzi do głosu również ich własna symbolika. Figury te wiążą się z symboliką graficzną, zakorzenioną w przestrzeni, liczbie i formie geometrycznej, ze względu na analogię, możliwe podobieństwo, wewnętrzny związek między dziełami człowieka i Stwórcy ${ }^{38}$. Jak pisze Jean Eduardo Cirlot: „Idee symboliczne bądź mityczne ujawniajace wpływ, pokrewieństwo bądź refleks jakiejś formy lub figury naturalnej, uzyskują od tej relacji potężny kontekst symboliczny"39.

Zauważone w konstrukcji pomnika grobowego Anny Wazówny trzy figury geometryczne symbolizują relację, co oznacza trójkąt między ziemią - oznaczona przez kwadrat - oraz niebem wyrażonym przez okrag.

38 J. E. Cirlot, Figury, [w:] Stownik symboli, s. 130-131. Cirlot (Graficzny [znak], s. 149) pisze, że w „każdej figurze graficznej musimy uwzględnić następujące elementy: a) podobieństw od postaci istot kosmicznych, b) forma otwarta lub zamknięta, regularna lub nieregularna, geometryczna lub biomorficzna, c) liczba elementów tej formy i sens owej liczby, d) rytmy dominujące, elementarny sens ich napięcia i ruchu, e) uporządkowanie przestrzenne, określenie stref, f) proporcje, g) ewentualne kolory".

39 J. E. Cirlot, Figury, s. 130-131. „Przykłady wzięte z analiz morfologicznych - pisze Cirlot - można przełożyć na język symboliczny [...] forma kolista, wyemanowana, oznacza równomierne rozchodzenie się jakiejś siły, istnienie jakiegoś centrum-źródła oraz jednorodnego medium stawiającego opór. Dokładanie te same prawa obowiązuja w sferze duchowej [...] trapez, prostokat, kwadrat, koła są fazami stopniowego przechodzenia od nieregularności do regularności, co świetnie mogłoby symbolizować rozwój moralny. Według Junga kwadrat, jako najmniejsza liczba mnoga (symbol położenia w przestrzeni), przedstawia stan (duchowego) rozbicia właściwy człowiekowi, który nie osiagnął jeszcze wewnętrznej jedności. [...] Symbole mają sensy w różnych płaszczyznach, głównie psychologicznej i kosmicznej. Na przykład w aspekcie psychologicznym trójkąt w swej zwykłej pozycji wierzchołkiem ku górze i umieszczony między kwadratem a kołem jest również elementem komunikacji. Obiektywnie jednak te trzy figury symbolizują relację (trójkąt) między ziemią (kwadrat) a niebem (krag, koło, rozeta), toteż stanowią symbol na wielu portalach cysterskich i gotyckich. Trzeba też mieć w pamięci prawo, zgodnie z którym formy wyjaśniają przedmioty, a przedmioty wyjaśniają formy. Znaczy to, że symbolikę jakiejś istoty bądź figury zwykle podkreśla bądź rozszerza sens ich formy i vice versa. [...] Na ogół formy płaskie mają charakter bardziej duchowy niż bryłowate, te zaś ściśle koresponduja z elementami makrokosmosu". Cirlot pisze, że w rozważaniach nad symboliką form zasadnicze znaczenie ma figura przekroju albo plan. Koło i kwadrat symbolizuja też nieograniczenie i ograniczenie (J. E. Cirlot, Formy, s. 132-134). 
Znaczenie relacji między kołem a kwadratem jest ogromne, formy zawierające najrozmaitsze odmiany tych figur obficie występuja nie tylko w sztuce religijnej i symbolicznej, ale także świeckiej. Koło jest obrazowym przedstawieniem pełni i doskonałości oraz wieczności, ponieważ nie ma ani początku, ani końca. Koło i kulę uważano za symbol wieczności Boga oraz odnoszono do wiecznego kolistego ruchu kosmosu, gdyż „podobnie jak linia koła powraca do swego punktu wyjścia, tak samo ziemskie życie stworzenia. W tym sensie - jak komentuje Dorothea Forstner - figura ta staje się wyrazem najwyższego prawa przyrody władającego wszelkim życiem i tym samym obrazem owej nieśmiertelności, rodzącej się z wciąż odnawiającego się życia, które powstaje $z$ obumierającej natury" ${ }^{\prime 40}$. W takim rozumieniu koło umieszczano na antycznych pomnikach grobowych w charakterze symbolu apoteozy, zdobiło także urny z prochami; zostało wykorzystane w ornamentyce i architekturze.

W pomniku grobowym królewny Anny Wazówny, dzięki zastosowaniu wspomnianych figur geometrycznych, znalazły zastosowanie zależności wyrażone poprzez związaną z nimi symbolikę, o której pisze Cirlot, wskazując na potęgę logiczno-symbolicznego podłoża figury. Badacz twierdzi, że „gdy chcemy przywołać abstrakcyjny obraz kosmicznego uporządkowania relacji - napiętej i głębokiej - między «dwoma światami», musimy zwrócić się do coniunctio symbolu ziemi (kwadrat) i nieba (koło)", co w sposób wyrazisty funkcjonuje w kompozycji toruńskiego pomnika. Warto też $\mathrm{w}$ tym kontekście przytoczyć dalsze słowa wspomnianego autora:

Fakt, że figury promieniującego centrum (koła) symbolizuja w aspekcie kosmicznym ostateczne przeznaczenie ducha, jest powodem, iż w aspekcie psychologicznym symbolizują one obraz tego przeznaczenia, jego przeczucie i drogę jego urzeczywistnienia, tzn. ideę mistyczną par excellance. Dlatego psychoanalitycy wskazują, że połączenie kwadratu z kołem, gwiazda, różą, lotosem, kołami koncentrycznymi, kołem z punktem centralnym itp. symbolizuje finał procesu indywidualizacji albo „zbawienia” w doktrynach mistycznych, tzn. etap życia duchowego, na którym wyeliminowane już są niedoskonałości (figury nieregularne), a także motywacje życiowe (symbole biologicz-

40 D. Forstner, op. cit., s. 57. 
ne w postaci najgorszych - potworów, dzikich zwierząt), następuje zaś skupienie w jedności i obrazie, jakie Dante umieszcza na końcu swego Raju ${ }^{41}{ }^{42}$.

\section{Kotara-zasłona}

Ukazane w dziele sztuki sepulkralnej drzwi mają ogólne znaczenie granicy pomiędzy dwoma rodzajami egzystencji. Rozdzielenie to bywało określane także w inny sposób. Ideę granicy pomiędzy dwoma światami wyrażały też elementy architektoniczne. Funkcjonalne podobieństwo do drzwi wykazuja też arkady obramowujące postacie zmarłych w gotyckich płytach grobowcowych. Te architektoniczne obramowania oddzielają nadnaturalną

${ }^{41}$ Dante, w ostatnich wierszach swej Boskiej Komedii, w których oddaje się kontemplacji Trójcy świętej, która ukazuje się mu jako trzy idealnie równe kręgi o różnych barwach, oznaczające symbol Boga Ojca (pierwszy krag), Syna Bożego (pierwszy krag odbity w drugim) oraz Ducha Świętego (trzeci krąg roztapiający się w dwóch pozostałych), aby wyrazić to, że Chrystus (drugie koło), pozostając Bogiem, jest jednocześnie człowiekiem, nadaje mu kształt i koła i człowieka (zob. J. Gałuszka, Przypisy, [w:] Dante Alighieri, Boska Komedia, przeł. E. Porębowicz, Warszawa 1990, s. 641). Dante napisał: „Na owym Kole, które z siebie brane, / Zda się promieniem z promienia odbitym, / Teraz oczyma moimi przystanę. / W nim, ale własnym malowany świtem, / Zjawił się Twarzy Człeczej Wizerunek... / Źrenice w niego wpoiłem z zachwytem. / Jak geometria wykreśla rysunek / Na kwadraturę koła i zestawia / Z nieupewnionych danych swój rachunek, / Tak mnie zjawienie nowe zastanawia: / Podpatrzeć chciałem, jako się sprzymierza / Figura z Kręgiem i jak się weń wjawia. / Lecz nie wystarczał lot ziemskiego pierza... / Wtem grom mię raził; myśl w cudo się grąży, / Czułem, że wola Jego w nią uderza. / Dalej fantazja moja nie nadąży. / A już wtórzyła pragnieniu i woli / Jak koło, które w parze z kołem krąży, / Miłość, co wprawia w ruch słońce i gwiazdy”. Cyt. za: Dante Alighieri, op. cit., s. 489-490. Kwadratura koła dotyczy utożsamienia się dwu wielkich symboli kosmicznych. Określanego przez koło nieba oraz ziemi reprezentowanej przez kwadrat. Istotą tego zestawienia jest osiagnięcie jedności pierwiastka materialnego i życia duchowego ponad opozycjami czwórki i kwadratu (J. E. Cirlot, Kwadratura koła, s. 216). Naszym zdaniem posłużenie się w tekście przez Dantego tym terminem miało unaoczniać zespolenie dwóch pierwiastków w osobie Syna Bożego - boskiego i ziemskiego (,Jak geometria wykreśla rysunek / Na kwadraturę koła i zestawia: / Z nieupewnionych danych swój rachunek", cyt. za: Dante Alighieri, op. cit., s. 489, w. 133-135). Odwołanie do światowej literatury potwierdza powszechne rozumienie symboliki figur geometrycznych, które wykorzystano w formach toruńskiego pomnika dla oddania spraw w jego treści zasadniczych, a niemożliwych dla ludzkiego zrozumienia w inny, niż symboliczny, sposób.

42 J. E. Cirlot, Graficzny [znak], [w:] Stownik symboli, s. 147-148. 
przestrzeń od rzeczywistej. Innym sposobem wyznaczenia granicy światów było stosowanie zasłony symbolicznie oddzielającej obserwatora od świętej akcji, jak w Poktonie pasteray Hugo van der Goesa (ok. 1480, Staatliche Museen, Berlin), gdzie prorocy odsłaniają tajemnicę, czy później w obrazie Madonny z drieciatkiem Rembrandta (1646, Staatliche Museen, Kassel), częściowo zakrytej przez zasłony, które odgrywaja także symboliczną rolę w kompozycjach epitafijnych i sepulkralnych ${ }^{43}$.

We Włoszech zasłona była dobrze znanym elementem sztuki sepulkralnej, a dzieła wykorzystujące ten motyw pojawiły się już w XIV wieku. Zasłona występowała w nich w kontekście znaczeniowym, który w rozważaniach dotyczących funkcji symbolicznej form zastosowanych w pomniku grobowym Anny Wazówny jest istotny. Wiadomo - pisze Jan Białostocki - że ,zasłona w malarstwie katakumbowym oznaczała próg raju, dokąd wchodzi zbawiony prowadzony przez święte postacie" ${ }^{44}$, i podkreśla, że $\mathrm{w}$,wielu włoskich grobowcach z XIV wieku aniołowie odsuwają na bok zasłony dzielące rzeczywistą ziemską przestrzeń od tej, w której przebywa zmarły". Za przykład może posłużyć tu np. grobowiec Robera d'Anjou wykonany przez Giovanniego i Pacio da Firenze pomiędzy 1343 a 1345 rokiem w Santa Chiara w Neapolu ${ }^{45}$. W nagrobku kardynała Guillaume’a de Braye (zm. 1282) w San Domenico w Orvieto, autorstwa Arnolfa di Cambio $^{46}$, zmarły leży na posłaniu, a dwie postacie (anioły?) odsłaniaja zasło-

43 J. Białostocki, Symbolikea drzwi w sepulkralnej squtuce baroku, s. 116.

44 J. Białostocki, Drami śmierci, s. 169, przyp. 40 na tej stronie.

45 Jan Białostocki w tej kwestii przypomniał opinię Henriette `s-Jacob, która wyjaśniała ten motyw jego starożytnym rodowodem, przypominając, że w domach rzymskich patrycjuszy istniał specjalny sługa, zwany velarius, którego zadaniem było odsłanianie i zaciąganie kotar dzielących przestrzeń wewnętrzną, oraz reprodukując malowidło ścienne ze starochrześcijańskiego cmentarza w Ciraco, na którym wspomniany sługa odsłania zasłonę, aby wpuścić orantkę (zob. J. Białostocki, Drzwi śmierci, il. 88). Białostocki podkreślił jednak, że dokładane znaczenie takich starożytnych przedstawień nie jest znane i ,nie ma też pewności, czy istniał związek pomiędzy nimi i zasłonami przedstawianymi we włoskich nagrobkach z XIV wieku, w których pojawia się motyw kotary oraz odsłaniania zmarłego przebywającego w innej rzeczywistości” (ibidem, s. 169).

46 Zob. il. E. Panofsky, Grabplastik. Vier Vorlesungen über ibren Bedeutungswandel von Alt- Ägypten bis Bernini, Herausgegeben von H. W. Janson, Deutsche Übersetzung von L. L. Möller, Köln 1965, il. 333 oraz s. 84. 
nę, która otacza całą figurę (także po bokach i z tyłu) ${ }^{47}$. W nagrobku arcybiskupa Simone'a Saltarellego (zm. 1342) w Santa Caterina w Pizie, autorstwa Nina Pisano ${ }^{48}$, zmarły leży na posłaniu pod kolumnowym baldachimem, a anioły odsłaniają kotarę, jednocześnie umożliwiając zobaczenie figury zmarłego. W dziele Giovanniego Dalmata i Andrea Bregno upamiętniającym kardynała Bartolommeo Roverella (1483) w San Clemente w Rzymie ${ }^{49}$ widzimy odsłonięte kotary po bokach wnęki, w której na sarkofagu spoczywa zmarły. Podobnie w dwu zabytkach znajdujących się w Santa Chiara w Neapolu: w nagrobku Roberta dem Weisen von Anjou (zm. 1343) oraz księcia Karla von Kalabrien (zm. 1328) autorstwa Tino da Camaiano anioły odsłaniają zasłonę i ukazują zmarłego leżącego na posłaniu w otoczeniu figur cnót i apostołów ${ }^{50}$. W realizacji architektoniczno-rzeźbiarskiej Donatella i Michelozza, jaką jest nagrobek antypapieża Jana XXIII (Baldassare Coscia, zm. 1419) w baptysterium we Florencji ${ }^{51}$, figura zmarłego leży na posłaniu na marach, a nad nią przedstawiona została odsłonięta zasłona, tworzaca rodzaj baldachimu. W nagrobku autorstwa Antonia Rosselino (1461-1466) upamiętniającym Kardynała Portugalskiego (zm. 1459) w San Miniato al Monte we Florencij ${ }^{52}$, kotara zawieszona została na łuku niszy, odsłonięta, skręcona i podwieszona z utworzeniem charakterystycznych pętli podtrzymujących ściagniętą tkaninę, która potem spływa swobodnie do dołu po obu stronach. Jest ona odsunięta i podwiązana (podobnie ukształtowane zostały kotary zredukowane do formy chust w przyłuczach portalu pomnika grobowego Anny Wazówny). Odsłonięcie kotary ukazu-

47 Podobnie za zmarłym ukazana jest z przodu całkowicie odsłonięta tkanina w nagrobku biskupa Guillaume'a Duranda von Mende (zm. 1296) autorstwa Giovanniego di Cosma, znajdującego się w Santa Maria Sopra Minerva w Rzymie. Anioły stoja po obu bokach niszy w głowie i w nogach figury zmarłego, ale gest odsłaniania nie został uwypuklony. Zob. E. Panofsky, op. cit., il. 334 oraz s. 85.

48 Zob. ibidem, il. 336 oraz s. 85

49 Zob. ibidem, il. 340, oraz s. 86.

50 Zob. ibidem, il. 398 oraz s. 95; il. 397 oraz s. 394. Anioły odsłaniające figurę zmarłego występowały też w nagrobku Cesarza Henryka VII (zm. 1313) autorstwa Tina da Camaiano. Zob. rekonstrukcję [w:] ibidem, il. 395, oraz nagrobek w Campo Santo w Pizie, il. 396 oraz s. 94.

51 Zob. ibidem, il. 323 oraz s. 82 .

52 Zob. ibidem, il. 318 oraz s. 85 . 
je niszę grobową zamknięta szerokim łukiem arkady, pod którym znajduje się leżąca postać zmarłego. Połączenie dwu elementów wyznaczających granicę światów występuje w nagrobku papieża Aleksandra VII (1671-1678) w Bazylice św. Piotra w Rzymie autorstwa Giana Lorenza Berniniego, gdzie ogromna kotara jest usytuowana nad rzeczywistymi drzwiami znajdującymi się w obrębie dzieła, którą podtrzymuje szkielet trzymający klepsydrę. Podwiązanymi chustami-kotarami udekorowana są też ściany kaplicy Kołudzkich w katedrze w Gnieźnie, której formy wystroju wykazuja pokrewieństwo $z$ toruńskim pomnikiem grobowym ${ }^{53}$. Warto zwrócić uwagę na funkcjonowanie tego motywu także w sztuce sepulkralnej poreformacyjnej Anglii, gdzie właśnie w wieku XVII odnajdujemy przykłady zastosowania kotar w nagrobkach. Należą do nich epitafijne w formie pomniki Edwarda Lambe, zmarłego w roku 1617, w kościele St. Mary w East Bergholt (w hrabstwie Sufolk), sir Roberta Chamberlayne'a, zmarłego w roku 1615, zamieszczonego na północnej ścianie chóru kościoła St. Bartholomew the Great w City of London oraz sir Drue'a Drury'ego (?1531-1617) w kościele St. Peter w Riddlesworth (w hrabstwie Norfolk), gdzie w centralnej części zabytków dwa anioły odsłaniaja kotary, by ukazać zmarłego przedstawionego w pozycji klęczącej w akcie modlitwy. W omawianym kontekście zwraca szczególną uwage pomnik grobowy Alice Spencer, hrabini Derby, zmarłej w roku 1637, znajdujący się w pobliżu ołtarza głównego w kościele St. Mary w Harefield (w historycznym hrabstwie Middlesex), w którym leżąca na wznak figura zmarłej znajduje się pod kopułowym w kształcie baldachimem wspartym na czterech kolumnach, z którego spływa tkanina tworząca poniżej partii belkowania podwiązane na kolumnach kotary, odsłaniające zmarła ${ }^{54}$. Motyw kotar stosowanych w nagrobkach dotarł także na tereny dzisiejszej Irlandii. W katedrze św. Patryka w Dublinie występuje on w pomniku Richarda Boyle i jego rodziny (1632), gdzie są one

53 Zob. A. Saar-Kozłowska, Problem autorstwa myposaženia architektonično-rzeźbiarskiego kaplicy

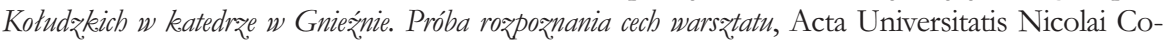
pernici. Zabytkoznawstwo i Konserwatorstwo XXXVIII. Nauki Humanistyczno-Społeczne, z. 394 , Toruń 2010 , s. $15-87$, il. 4, s. 53 , 5, s. 54 , 35, s. 79 , 36, s. 80 . Kotary występują też w charakterze motywu dekoracyjnego w podłuczach naczółka ołtarza kaplicy

54 Zob.: N. Llewellyn, Funeral Monuments in Post-Reformation England, Cambridge 2000, il. 91 , s. 128 , il. 95 , s. 133 , il. 183 , s. 295 , il. 198 , s. 319. 
podwieszone i podtrzymywane przez aniołki dzięki czemu można ujrzeć zmarłego i jego małżonkę ${ }^{55}$.

Powyższe spostrzeżenia pozwalają na stwierdzenie, że pomnik grobowy królewny Anny Wazówny należy do grupy zabytków, które ukazuja zmarłego w wizji zaświatowej, urzeczywistnionej przed widzem przez dzieło sztuki. Takie ich elementy, jak drzwi, kotary i łuki, określaja miejsce prezentacji zmarłego jako sferę pozaziemska, a umieszczona ponad nimi kopuła dodatkowo precyzuje to miejsce jako niebo. W przypadku toruńskiego zabytku rolę oznaczenia granicy światów spełniaja wspomniane już wcześniej: łuk portalu oraz kopuła, a także zredukowane kotary.

\section{Kopuła}

Formy, które zastosowano w pomniku grobowym królewny Anny, sięgają do dawnej tradycji symboliki niebiańskiej Jerozolimy, wyrażanej niegdyśs poprzez elementy bardziej rozbudowane i łatwiej czytelne w swej funk$\mathrm{cji}^{56}$, tu zaś sprowadzone do prostych, abstrakcyjnych znaków figur geometrycznych wyrażających jednakże ideę przebywania zmarłej w niebie, którą aż nazbyt jasno uczytelniały słowa panegiryku żałobnego Opitza, stanowiącego komentarz do wydarzeń upamiętniających Wazównę w Toruniu w roku 1636.

55 Informacje na temat monumentu rodziny Boyle zob. A. Fenton, Past Lives. The Memorials of Saint Patrick's Cathedral, Dublin, Dublin 2012, s. 23-27.

56 Rzeczywista architektura naśladowała niebiańska Jerozolimę. Symboliczne znaczenie nieba wyrażały różne elementy architektoniczne. Bryła kościoła gotyckiego wzorowana na modelu niebiańskim wskazywała na społeczność zbawionych w niebie. Gotycka katedra był symbolem niebiańskiej Jerozolimy, wiodące do niej portale ewokowały bramy raju, bramy do nieba. Na niebo i na niebiańską Jerozolimę wskazywały baldachimy, pod którymi w portalu stali prorocy, patriarchowie i królowie Starego Testamentu oraz święci Nowego Przymierza. Dla ludzi czasów średniowiecza bramami, które wiodły do górnego Jeruzalem, były także baptysteria. Ideę murów i fundamentów Świętego Miasta nasuwały szlachetne materiały, którymi inkrustowano, oblicowywano, wykładano wewnętrzne ściany kaplic, funkcję „uzmysłowiania” - jak pisze Stanisław Kobielus - cennego materiału, wchodzącego w konstrukcję fundamentów i murów niebiańskiej Jerozolimy, pełniły wielobarwne szkła witraży w świątyniach. S. Kobielus, op. cit., s. 128-133. 
Formy baldachimów ${ }^{57}$ oraz kopuł były formami wypowiedzi plastycznej, które rozumiane jako symbol nieba polska sztuka sepulkralna zna znakomicie, czego dowodzą wawelskie przykłady nagrobków królewskich, choćby Kazimierza Wielkiego i Kazimierza Jagiellończyka, w których leżące figury zmarłych władców mają otwarte oczy, co symbolizuje kontemplację świata nadprzyrodzonego ${ }^{58}$. Przeniesienie znaczenia baldachimu na sklepioną kopułowo kaplicę reprezentuje kaplica Zygmuntowska. Zapewne z tego względu niewidoczna ani z zewnątrz, ani z prezbiterium kopuła toruńskiego pomnika grobowego Wazówny, choć nieforemna, lecz podkreślona gzymsem, została zrealizowana w tym, być może zredukowanym w swej formie w stosunku do pierwotnego projektu architektonicznego, kształcie. Stanowi ona realizację kopuły pozornej, opartej na łuku wspiętym od strony północnej ściany prezbiterium, który przechodzi w łuk półpełny w partii środkowej kaplicy. Oznacza ona, mimo swej niepełnej formy, ideę nieba ponad zamarła. Symbolizuje niebo, w którym zmarła przebywa, oglądając rzeczywistość zasłużonej szczęśliwości.

Ideę nieba jako miejsca przebywania zmarłej wyrażały też główne elementy nośne symbolicznie ceremonii pogrzebowej oraz jej komentarza słownego, jakim był panegiryk Marcina Opitza. Myśl tę podsuwał także zacytowany na otwartej księdze figury Wiary fragment Listu do Hebrajcaykoón $w^{59}$.

\section{Spirala i granat. Nadzieja na nowe życie}

Postument nagrobka Anny Wazówny ujmują elementy zdobnicze zbudowane z przeciwstawnie zawiniętych wolut oraz pęków owocowo-listnych, których forma pozwala na zidentyfikowanie ich jako owoców granatu. Już samo przedstawienie owoców może mieć znaczenie wanitatywne i być rozumiane jako wyrażenie myśli o przemijalności i krótkości ludzkiego życia.

57 S. Kobielus, op. cit., s. 130.

58 Ibidem, s. 168.

59 Kwestie te zostały omówione w drugiej części tekstu. Zob. pierwszy przypis niniejszego artykułu oznaczony gwiazdką. 
Tak samo jak krótkotrwałe jest istnienie dojrzałych owoców, które ulegna zepsuciu, podobnie zwiędna piękne kwiaty, rozwieje się dym, pęknie bańka mydlana, szybko umrą drobne istoty żyjące (owady, ślimaki) przedstawiane w bukietach kwiatów w martwych naturach.

Od najdawniejszych czasów owoc granatu miał szczególną symbolikę związaną zarówno z życiem, jak i śmiercią. Zaważyły na niej same cechy owocu, a także tradycja antyczna oraz biblijna. Ludzi fascynował czerwony kwiat drzewa granatu, żywa czerwień purpurowego jabłka, skórka kryjąca mnóstwo małych owoców wyglądających jak „oszlifowane małe rubiny”, miąższ „przeświecających pereł” zawierający ${ }^{60}$ słodko-kwaskowy sok. W sztuce chrześcijańskiej ten motyw dekoracyjny występował na mozaikach podłogowych, tkaninach, bordiurach, wśród roślin wyobrażających raj oraz przedstawieniach cykli pór roku (w zestawieniu z winogronem owoc granatu wyobrażał jesień ${ }^{61}$. Podobnie jak w Biblii rajski owoc, tak w czasach antycznych granat był owocem, którego spożycie zamknęło drogę do nie$\mathrm{ba}^{62}$. Dotyczy to powodu nieodwracalności skutków porwania Persefony, która znajdując się w królestwie zmarłych, pożywiła się kilkoma ziarenkami granatu ${ }^{63}$. Z tego względu owoc ten ma charakter chtoniczny, a w średniowieczu, w związku ze wspomnianym mitem, owoc granatu w rękach

${ }^{60}$ D. Forstner, op. cit., s. 164.

${ }^{61} \mathrm{~W}$ antyku pogańskim owoc granatu był atrybutem wielu bogiń, między innymi Hery, Demeter i jej córki Persefony, Ateny czy też fenickiej Asztarte (S. Kobielus, Florarium Christianum. Symbolika roślin - chrześcijańska starošytność i średniowiecze, Tyniec 2006, s. 79). Drzewo granatu z powodu mnogości swych nasion było symbolem pełni życia i płodności. Z tego względu należało do atrybutów greckich i orientalnych bóstw wegetacji (Hera, Adonis, Baal itd.). Hera trzymająca w rękach owoc granatu symbolizowała śmierć i zmartwychwstanie. W starożytnym Egipcie zmarłych chowano z owocem granatu jako nadziei na odrodzenie (ibidem). Z powodu czerwonej barwy jabłko granatu symbolizowało płomienną miłość i z tego względu było atrybutem bogini Afrodyty oraz znakiem krwi i śmierci.

${ }^{62}$ Ibidem, s. 79-80. Autor podaje, że według niektórych pisarzy powodem upadku pierwszych rodziców w raju było drzewo granatu. Moc i czerwień granatu miały wskazywać na cierpliwość podczas cierpienia.

63 Zob. Owidiusz, Przemiany (Metamorfosy), tłum. B. Kiciński, Kraków 2002, ks. V, s. $117-$ -124, Ceres i Prozerpina, w. 540-545 (s. 122-123). Czytamy tam: „[...] Już powrotu córki Ceres pewną była, / Lecz nie tak chcą wyroki, córka post zgwałciła. / Gdy bowiem po przepysznym błaka się ogrodzie, / Z pochylonego drzewa granat rwie w przechodzie / i siedm jąder wyssała". 
Dzieciątka Jezus stał się symbolem zmartwychwstania ${ }^{64}$. Na terenach Italii znajdowano na starożytnych grobach gliniane jabłka granatu, które moga być interpretowane jako symbole nadziei przyszłego życia. Podobne znaczenia ma - jak pisze Dorothea Forstner - przedstawianie tego owocu w scenach uczty pogrzebowej ${ }^{65}$. Zauważalna sprzeczność symboliki owocu granatu, rozpiętej pomiędzy wyrażaniem życia i śmierci, jest pozorna i znajduje swoje uzasadnienie w charakterze mitów, w których niejednokrotnie chodzi o personifikowanie sił natury i wyrażenie przekonania, że śmierć jest warunkiem nowego życia, a krew warunkiem jego zrodzenia ${ }^{66}$.

Pogańska symbolika granatu związana z płodnością została w chrześcijaństwie przeniesiona na sferę ducha ${ }^{67}$. Owoc ten nabiera szczególnego znaczenia symbolicznego $\mathrm{w}$ zestawieniu $\mathrm{z}$ innymi motywami ${ }^{68}$. Można go zaobserwować też w portretach oraz w przedstawieniach religijnych. W ikonografii Matki Bożej granat może stanowić aluzję do jej dziewictwa, jak

${ }^{64}$ L. Impelluso, Natura i jej symbole. Rośliny $i$ zwierzeta, tłum. H. Cieśla, Warszawa 2006, s. 145 .

65 D. Forstner, op. cit., s. 164.

${ }^{66}$ Ibidem, s. 164-165. Owoc granatu pojawia się w Piśmie Świetym w Starym Testamencie - wśród owoców przyniesionych z ziemi Kanaan. Dla narodu wybranego owoce granatu były znakiem błogosławieństwa Bożego, obiecanym za dochowanie wierności prawu. W Pieśni nad Pieśniami owoc granatu pojawia się 6 razy i oznacza miłość Oblubienicy i jej wewnętrzne piękno, które ukryte jest w jej zewnętrznym wdzięku („Jak okrawek granatu skroń twoja za twoją zasłoną", PnP 4,3; 6,7). Stanisław Kobielus (Florarium Christianum, s. 80) wskazuje na dekorowanie owocami granatu dwu kolumn Świątyni Salomona. Pisze też, że „podwojona liczba owoców granatu w wieńcach wokół głowic kolumn miała w sensie mistycznym wskazywać na ludy obu Testamentów zjednoczone w Chrystusie i doprowadzone do korony żywota wiecznego w królestwie niebieskim”.

${ }^{67}$ S. Kobielus, Florarium Christianum, s. 81. Dorothea Forstner (op. cit., s. 166) pisze, że w pismach ojców Kościoła jabłko granatu jest symbolem Kościoła. „W łupinie świętego milczenia kryje on pełnie tajemnic i nadzieje dóbr wiecznych".

68 D. Forstner, op. cit., s. 166. Na przykład na płaskorzeźbie marmurowej płyty (XII lub XIII wiek) z wyobrażeniem młodego lwa pożerającego sarnę, co oznaczało triumf światła (Lew - gwiazdozbiór, znak najsilniejszego żaru) nad ciemnością (futro młodych saren obrazem gwiaździstego nieba), nad którym wznosi się trzon kolumny zakończony naczyniem, z którego wyrasta szczep wypuszczający latorośle, flankowany przez pawie (symbole nieśmiertelności) umieszczone na dwu najniższych pędach. Jabłko granatu wieńczące pęd, jako symbol pełni życia, pozwala cały opisany motyw roślinny interpretować jako „drzewo życia”, a kompozycja może być dzięki temu odczytana jako „triumf wiecznego życia nad śmiercią i ciemnością. 
na przykład w Madonnie Magnificat Sandro Botticellego (1481-1485), gdzie w dłoniach Matki Bożej i dzieciątka może wskazywać na jego podwójną symbolikę - dziewictwa i zmartwychwstania.

W przypadku zastosowania motywu owocu granatu w pomniku grobowym Anny Wazówny istotna mogła być ogólna symbolika owoców, wyrażająca w duchu wanitatywnym przemijalność ludzkiego życia, oraz obrazowanie w ten symboliczny sposób nadziei na przyszłe życie. Tym bardziej że owocom granatu towarzysza przeciwstawnie skrętne woluty - spirale oznaczające ewolucję i inwolucję; przywodzące na myśl prastarą symbolikę tego związanego od czasów prehistorycznych ze sztuką sepulkralną motywu, oznaczającego oddech i ducha, wywołującego ekstazę i „ułatwiającego wyrwanie się z tego świata, aby wkroczyć w inny, po drugiej stronie" ${ }^{99}$. Jest to szczególnie wyraźne w kontekście bliskości leżącej figury zmarłej, usytuowanej powyżej, lekko unoszącej się na swym posłaniu przed obliczem Boga, kontemplującej otwartymi oczami świat nadprzyrodzony, w przypadku której - poprzez symbolikę całego dzieła - zbawienie - sytuowanie w niebie - miejscu nowego życia właśnie się dokonuje, oraz w kontekście treści komentarza słownego w postaci panegiryku Opitza - jest już ono faktem.

\section{Summary}

\section{The Eternal Bliss of Princess Anna In Heaven under the dome of sepulchral monument}

The Eternal Bliss is a dream of each believer on crossing the finishing line of his/her earthly journey and entering Heaven in reward for being just. As it comes to the biography of Princess Anna Vasa of Sweden and the events commemorating her that took place in Torun in 1636, we deal with three visions on the beyond. They are her personal experience of presence in the Third Heaven (1), the vision on her presence in Heaven created by the means of art on her sepulchral monument at the Assumption of the Virgin Mary Church (c. 1636) (2), and the parallel vision constructed during the funeral ceremony (3) and present in a panegyric that situates her in Heavenly Jerusalem, in which her name is written

69 J. E. Cirlot, Stownik symboli, s. 382-383. 
in the Book of Life and she is nourished by the living waters and connected to the Tree of Life.

All endeavours aimed at commemorating Princess Anna Vasa such as funeral ceremony, sepulchral monument and occasional literature are dual in their nature, ie. they are both mournful and distinctly triumphant. Thus on the sepulchral monument, despite its typical gloomy character, there are elements to be found that overtly indicate the state of Eternal Bliss in which the departed Princess is to rejoice. The elements include the monument's location in the chancel and such its architectural details as a portal in the shape of triumphal arch symbolizing the gate between the earthly and the spirit worlds, a dome as a symbol of Heaven, and a design for the sepulchral sculptures, that contains the lying figure of the Princess (with the eyes open and lost in contemplation of the spirit world; situated beyond the portal-gate and composed within the arch of the portal), and the set of three portal figures, standing for Princess' earthly achievements and opening the gate to Heaven for her in exchange for her faithfulness to the faith and its articles. The figures include the images of Fides (Faith), Gratitudine (Gratitude) - representing the help to our neighbours, and Vittoria (Victory) - denoting the victory in the earthly and heavenly dimensions. 


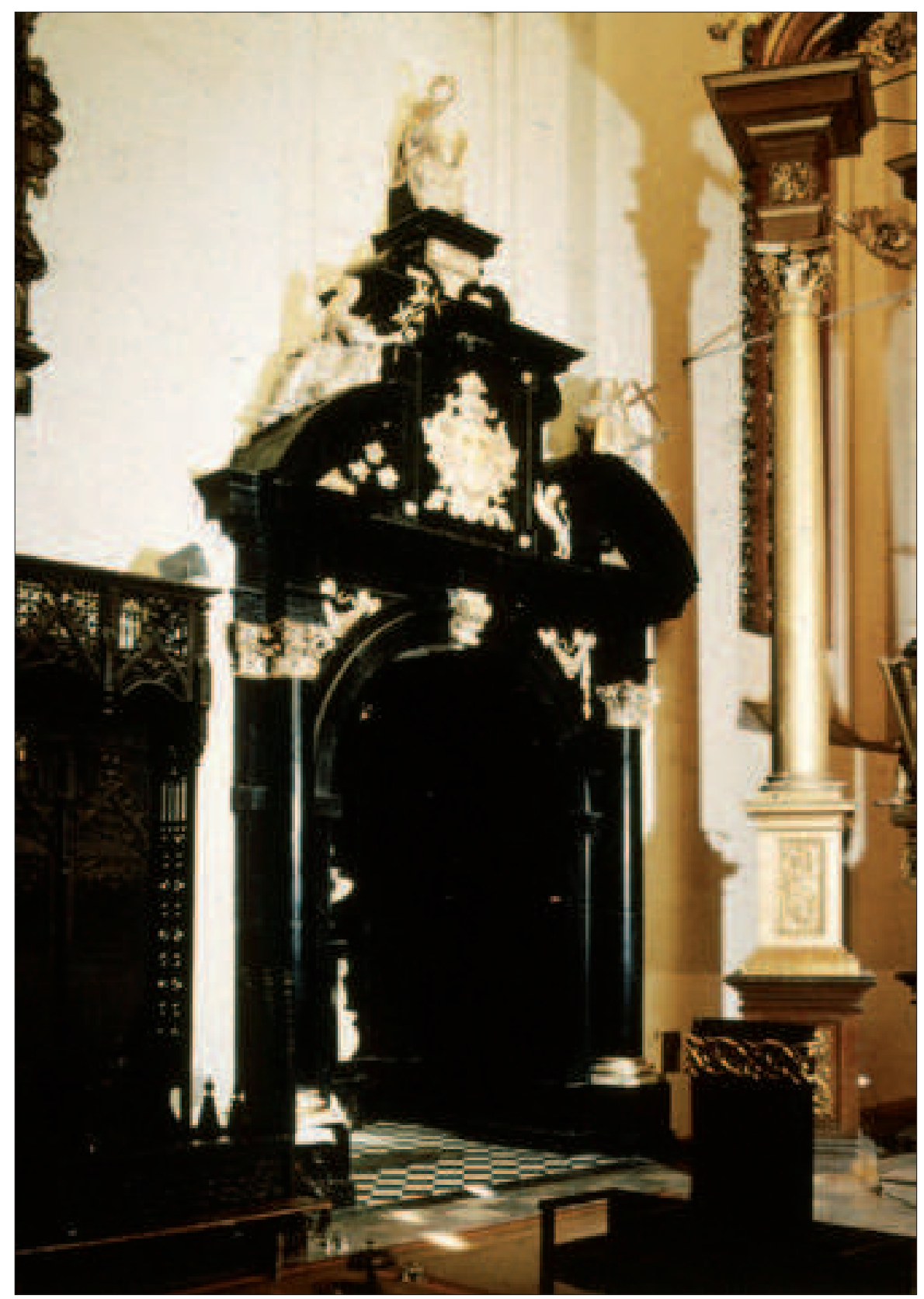

Il. 1. Portal pomnika grobowego Anny Wazówny w kościele Wniebowzięcia Najświętszej Marii Panny w Toruniu (ok. 1636); fot. 1995 Wacław Gorski, Andrzej Skowroński 


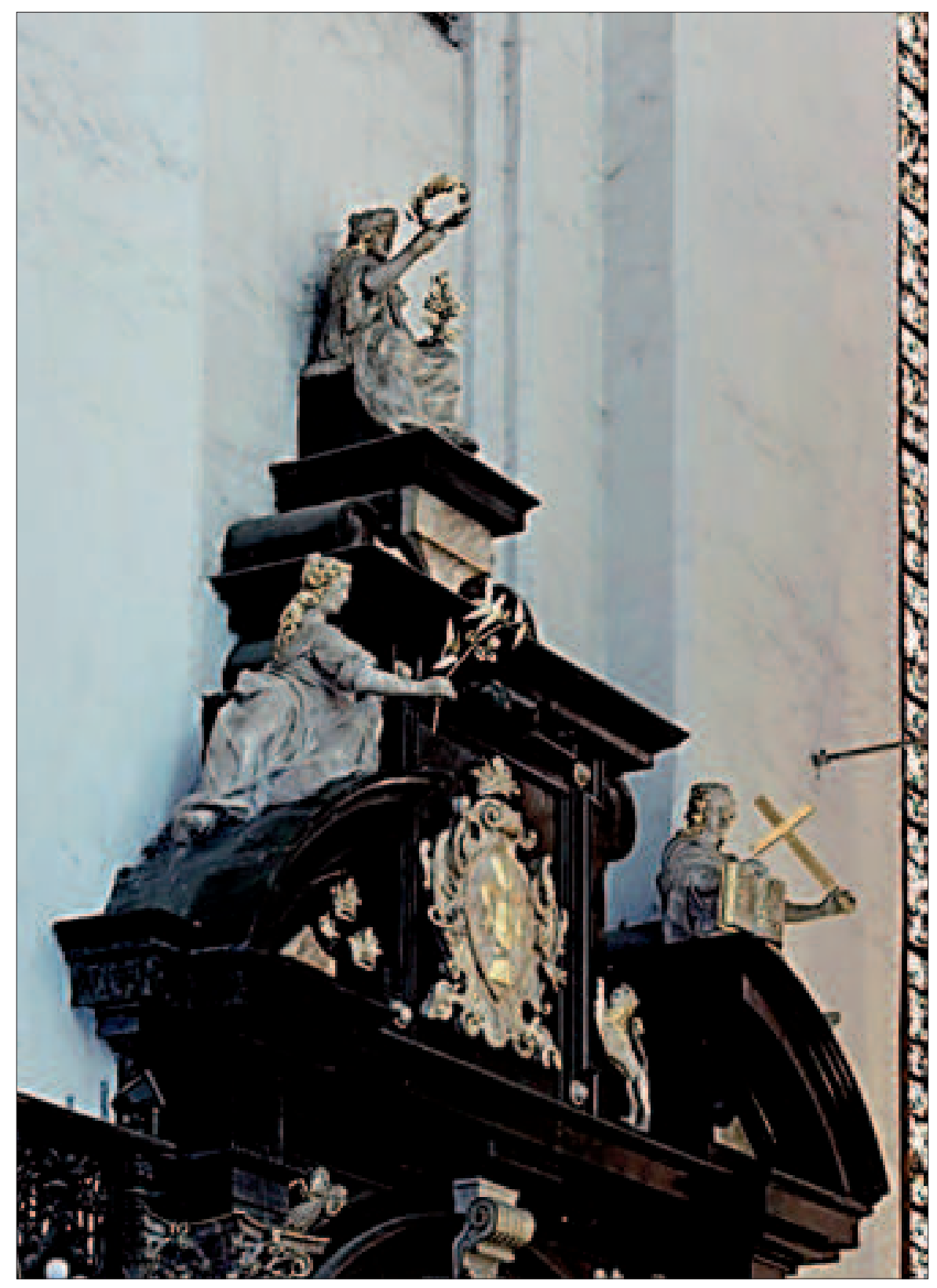

Il. 2. Fragment górnej partii portalu pomnika grobowego Anny Wazówny; zdjęcie ukazuje sposób oglądania zabytku przez widza $-\mathrm{z}$ boku, oraz sposób wyeksponowania atrybutów; fot. 2012 Mikołaj Saar-Kozłowski 


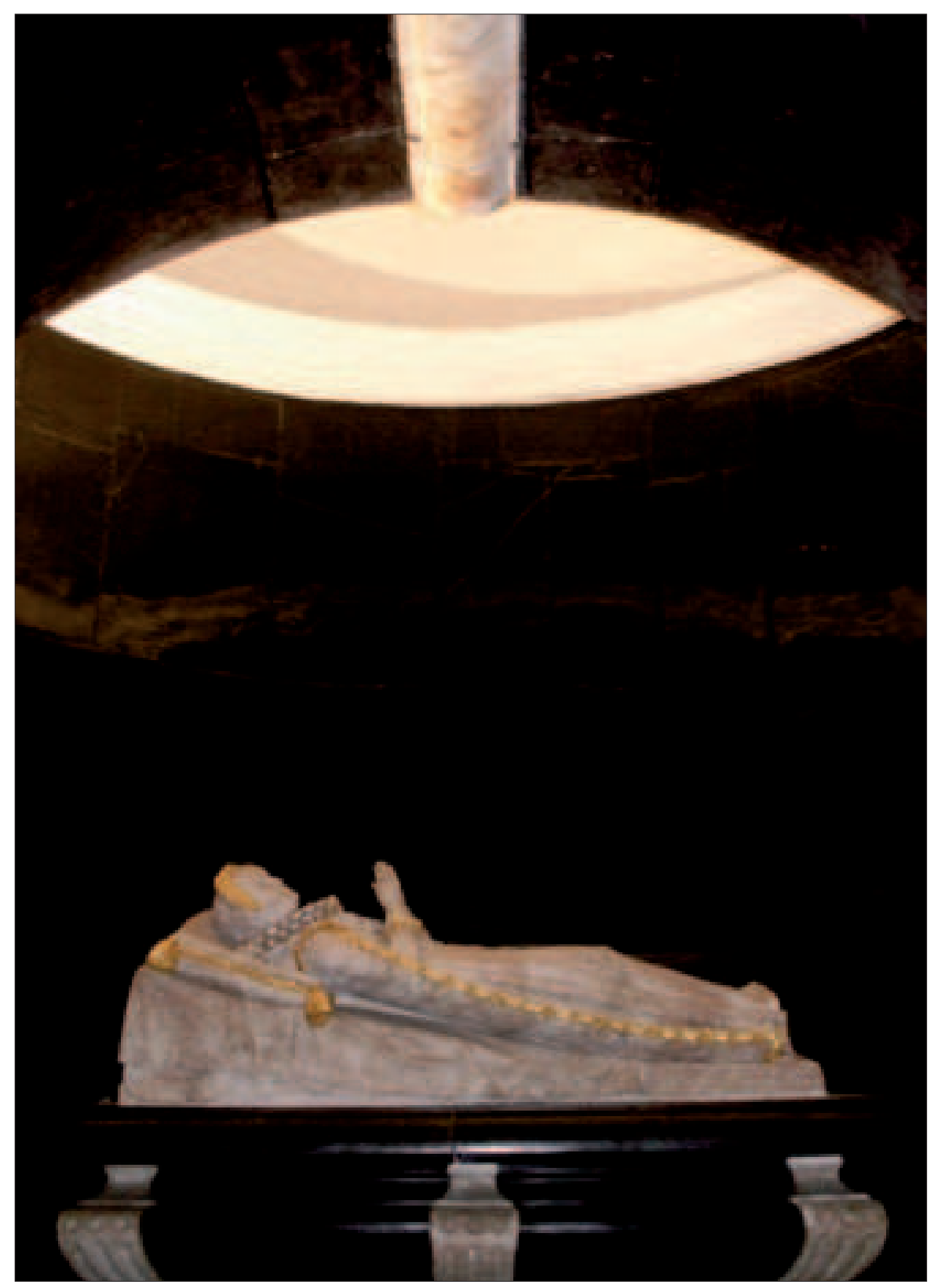

Il. 3. Figura Anny Wazówny leżąca na otwartym sarkofagu w niszy jej pomnika grobowego w kościele Wniebowzięcia Najświętszej Panny Marii w Toruniu; widoczny fragment oświetlonej sztucznym światłem nieforemnej kopuły; fot. 2006 Alicja Saar-Kozłowska 


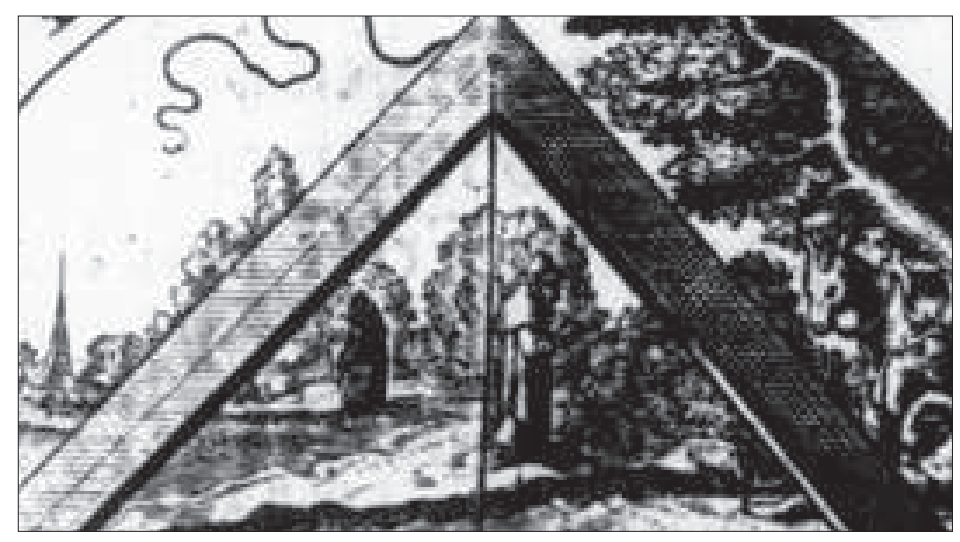

Il. 4. Emblem „Jesus Perfectio Nostra” z Sacra Emblemata ... Johanna Mannicha, Nürnberg 1624. Biblioteka Polskiej Akademii Nauk w Gdańsku, sygn. Ga 11 36. Dokumentacja rysunkowo-pomiarowa pomnika grobowego Anny Wazówny

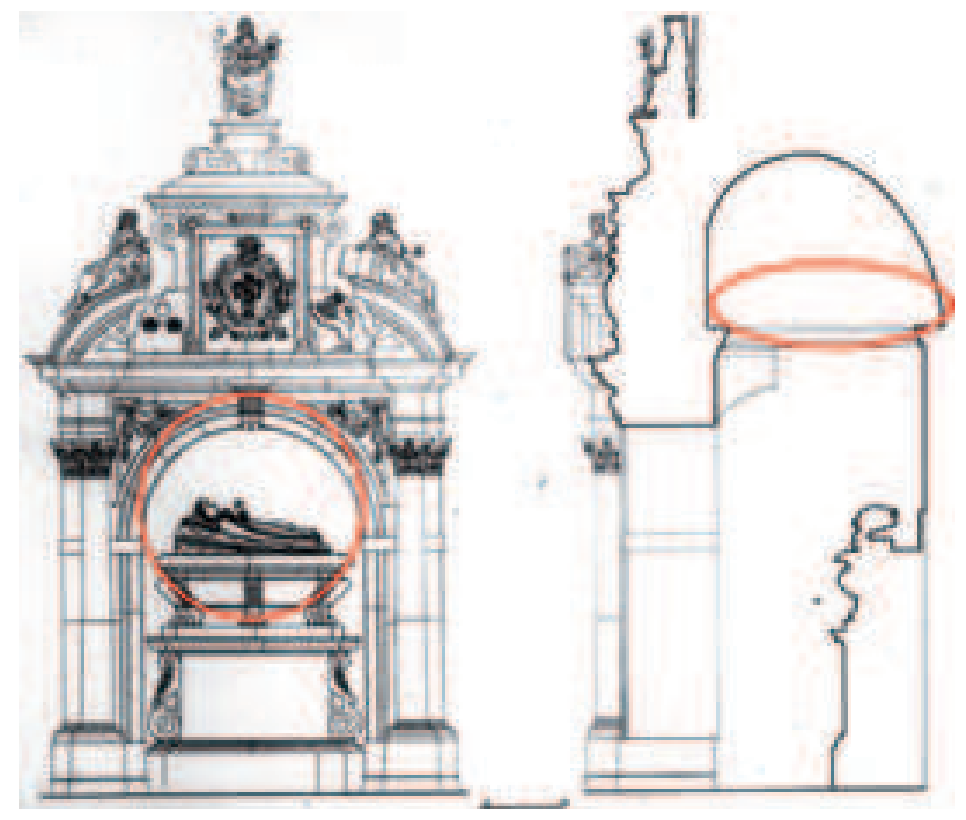

Il. 5. Koło jest symbolem nieba, a tym samym Niebiańskiej Jerozolimy. Jako znak graficzny oznacza nieskończoność, czyli wszechświat jako całość. Dokumentacja pomiarowo-rysunkowa pomnika grobowego Anny Wazówny (ok. 1636) w skali 1:20. Autorzy: J. Czajka, J. Dorau, 1979; ze zbiorów Dokumentacji Instytutu Zabytkoznawstwa i Konserwatorstwa Wydziału Sztuk Pięknych Uniwersytetu Mikołaja Kopernika w Toruniu 
[158]
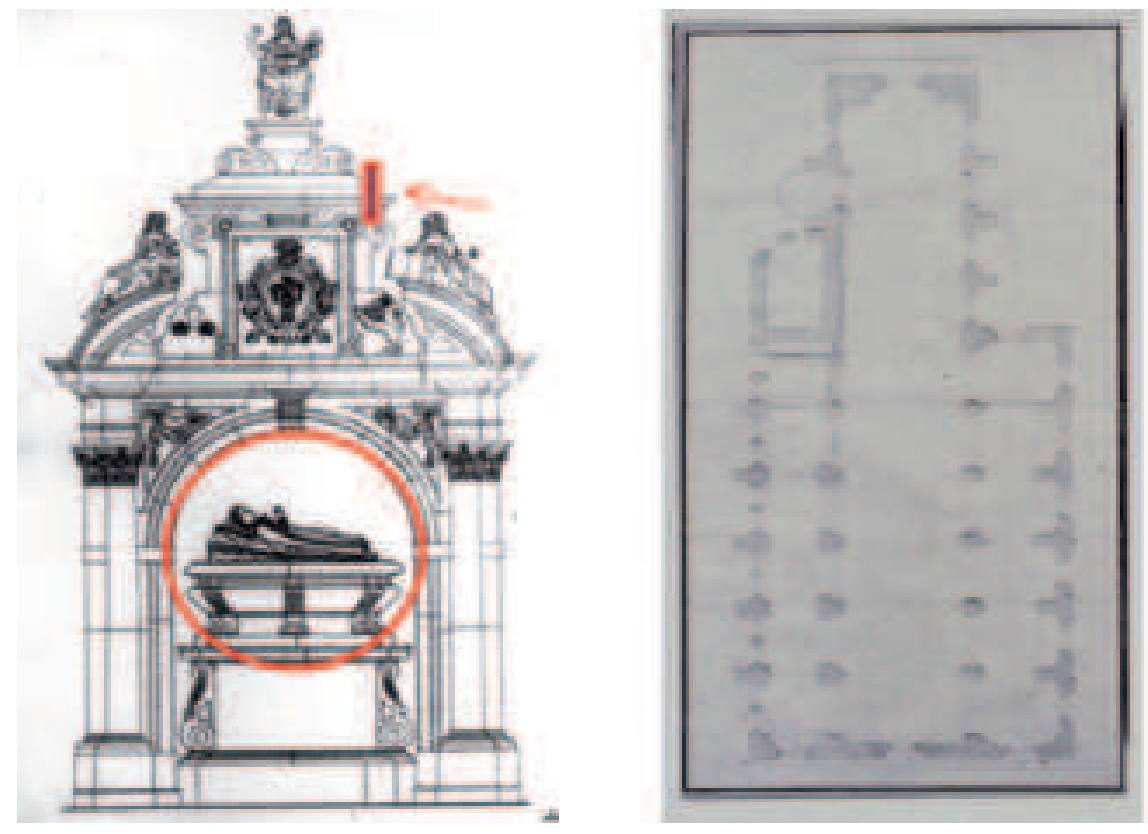

Il. 6. Figura zmarłej leży na średnicy koła powstałego z dopełnienia łuku arkady (wpisanego w łuk arkady). Jako znak graficzny koło podzielone poziomo na dwie połowy oznacza horyzont, czyli oddzielenie dwóch światów. Portal stanowi granicę świata ziemskiego i nieba powstrzymującą widza.

Po lewej: Dokumentacja rysunkowo-pomiarowa pomnika grobowego Anny Wazówny. Po prawej: przekrój poziomy kościoła WNP Marii w Toruniu Johann F. Bachstrom 1718) fot. Wacław Górski; elementy zaznaczone czerwonym kolorem naniesione przez autorkę 


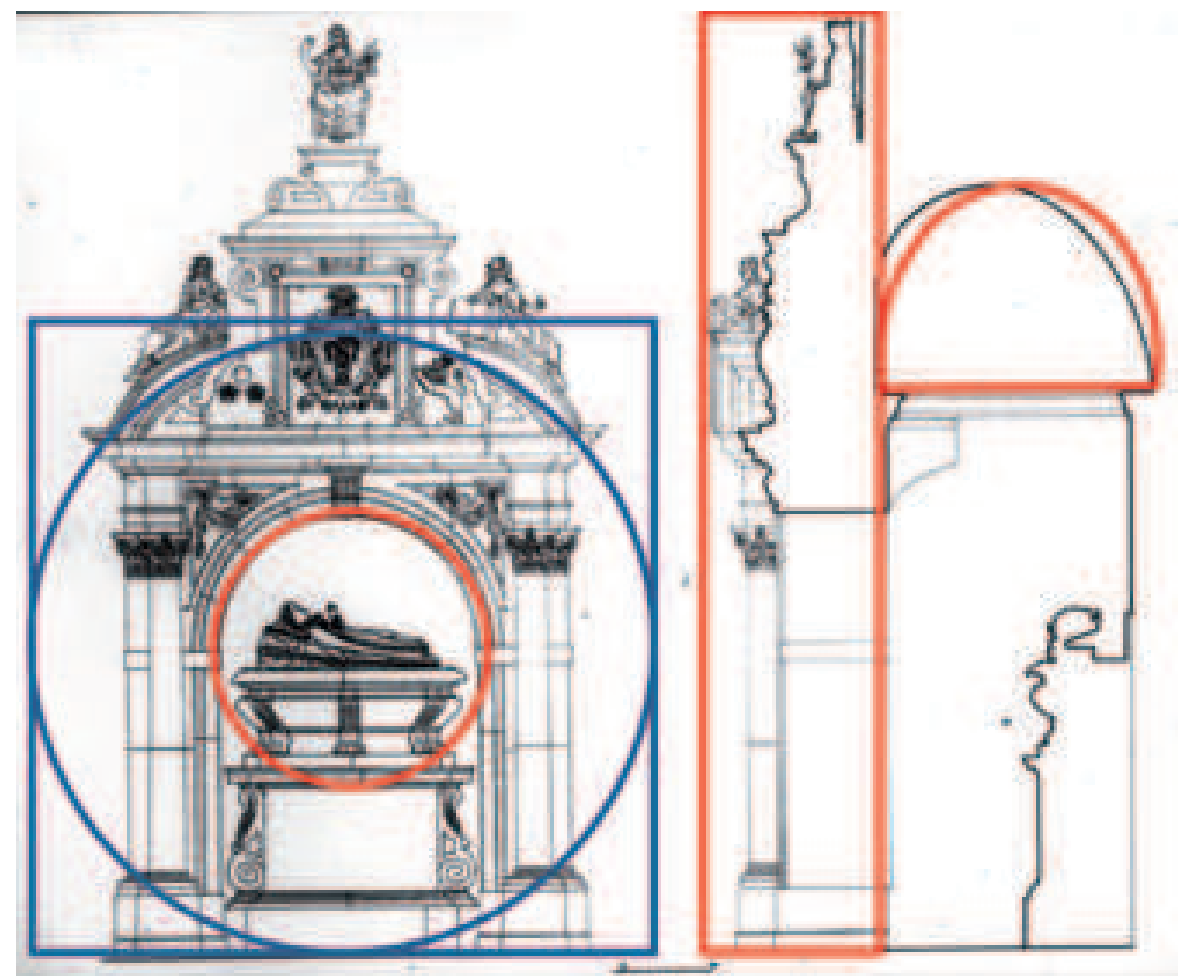

Il. 7. Dokumentacja rysunkowo-pomiarowa pomnika grobowego Anny Wazówny z naniesionymi wykresami konstruujących jego formę figur geometrycznych i z oznaczeniem portalu jako granicy ingerencji widza 


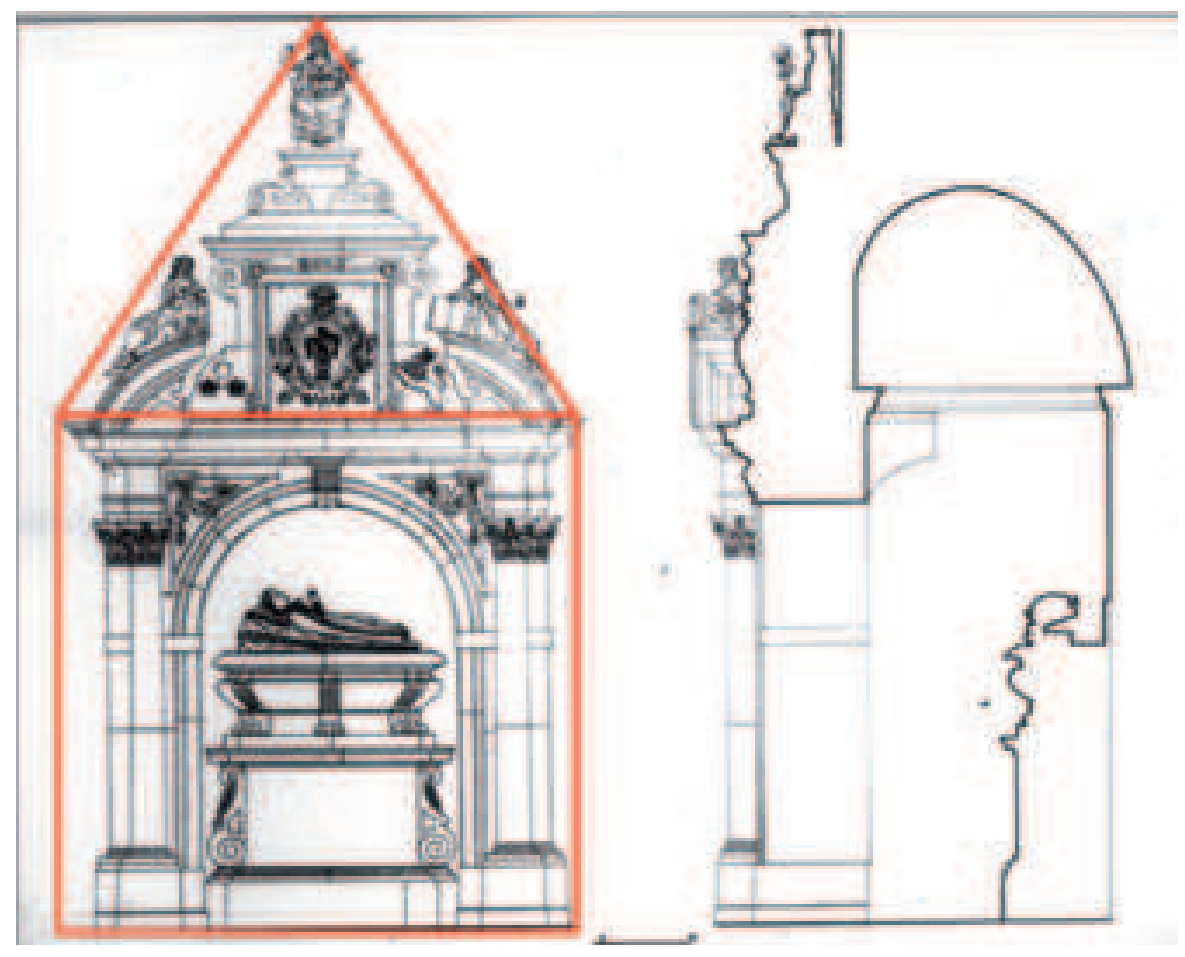

Il. 8. Dokumentacja rysunkowo-pomiarowa pomnika grobowego Anny Wazówny z naniesionymi wykresami konstruujących jego formę figur geometrycznych 


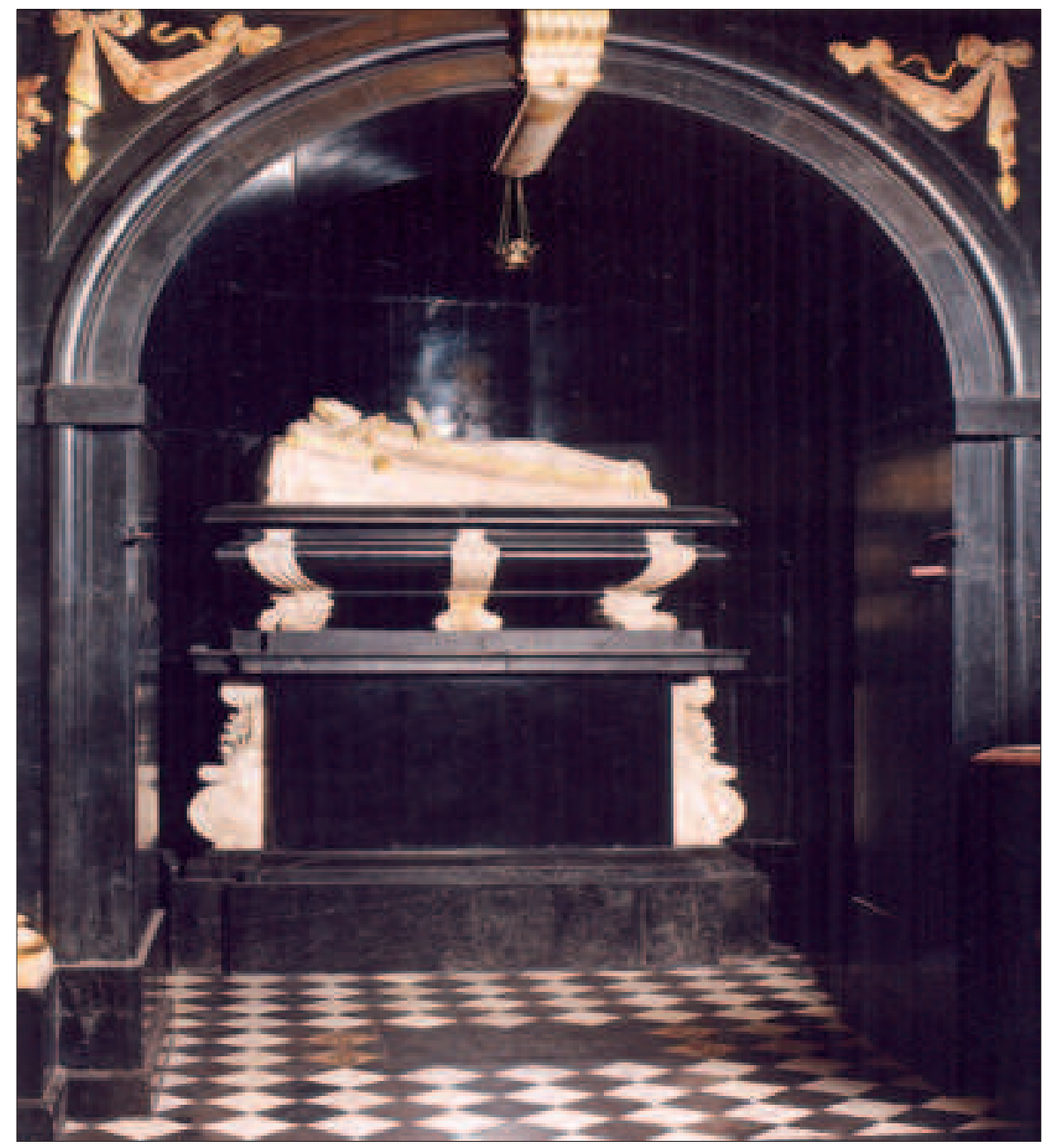

Il. 9. Nagrobek Anny Wazówny w niszy jej pomnika grobowego (ok. 1636); w przyłuczach widoczne chusty funkcjonujące forma zredukowanych kotar-zasłon; fot. 1996 Wacław Gorski, Andrzej Skowroński 

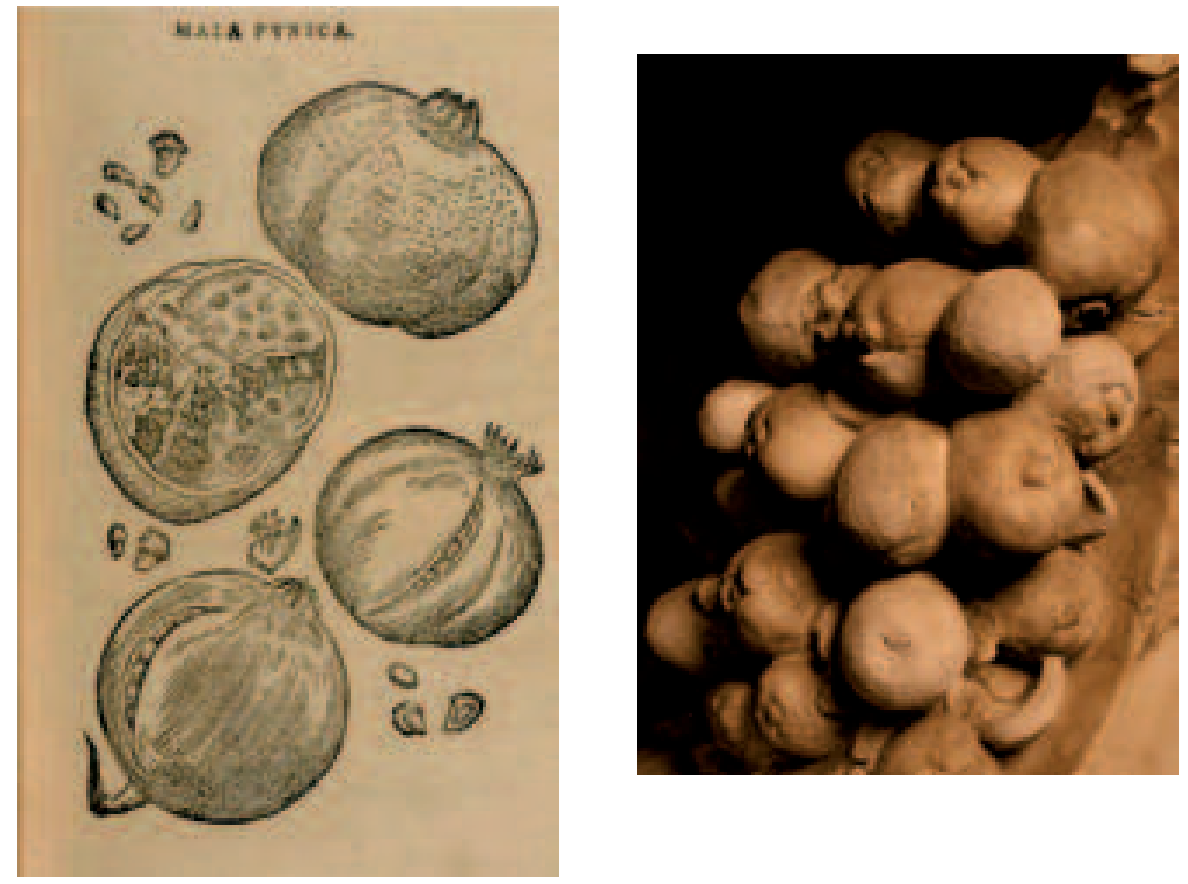

Il. 10. Po lewej: Pietro Andrea Mattioli, De plantis epitome utilissima Petri Andreae Matthioli, novis Iconibus et Descriptionibus pluribus nunc primum diligenter aucta, Camerarius, Joachim (ed.), Francofurti ad Moenum, 1586

Po prawej: fragment pęku owocowo-listnego zawieszonego na taśmie w spirali ujmującej postument nagrobka Anny Wazówny w kościele Wniebowzięcia Najświętszej Panny Marii w Toruniu (ok. 1636) 